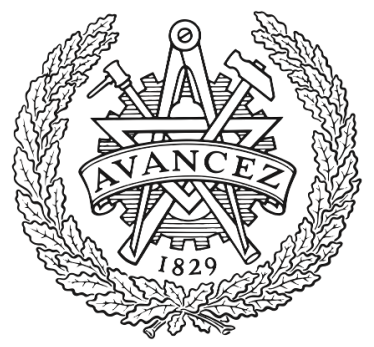

CHALMERS

UNIVERSITY OF TECHNOLOGY

\title{
A First-Principles Microkinetic Model for Low-Temperature NH3 Assisted Selective Catalytic Reduction of NO over Cu-CHA
}

Downloaded from: https://research.chalmers.se, 2023-04-26 13:42 UTC

Citation for the original published paper (version of record):

Feng, Y., Wang, X., Janssens, T. et al (2021). A First-Principles Microkinetic Model for Low-Temperature NH3 Assisted Selective Catalytic

Reduction of NO over Cu-CHA. ACS Catalysis, 11(23): 14395-14407.

http://dx.doi.org/10.1021/acscatal.1c03973

N.B. When citing this work, cite the original published paper. 


\title{
First-Principles Microkinetic Model for Low-Temperature $\mathrm{NH}_{3}$-Assisted Selective Catalytic Reduction of NO over Cu-CHA
}

\author{
Yingxin Feng,* Xueting Wang, Ton V. W. Janssens, Peter N. R. Vennestrøm, Jonas Jansson,
} Magnus Skoglundh, and Henrik Grönbeck*

Cite This: ACS Catal. 2021, 11, 14395-14407

Read Online

ACCESS

Џ Metrics \& More

回国 Article Recommendations

Supporting Information

ABSTRACT: A first-principles microkinetic model is developed to investigate the low-temperature ammonia-assisted selective catalytic reduction $\left(\mathrm{NH}_{3}\right.$-SCR) of $\mathrm{NO}$ over $\mathrm{Cu}$-chabazite $(\mathrm{Cu}-\mathrm{CHA})$. The reaction proceeds over $\mathrm{NH}_{3}$-solvated $\mathrm{Cu}$ sites by the formation of $\mathrm{H}_{2} \mathrm{NNO}$ and $\mathrm{HONO}$, which decompose to $\mathrm{N}_{2}$ and $\mathrm{H}_{2} \mathrm{O}$ over Brønsted acid sites. Nonselective $\mathrm{N}_{2} \mathrm{O}$ formation is considered by $\mathrm{H}_{2} \mathrm{NNO}$ decomposition over the $\mathrm{Cu}$ sites. The adsorption of $\mathrm{NH}_{3}$ at oxidized $\mathrm{Cu}$ sites is found to inhibit the reaction at low temperatures by hindering $\mathrm{NO}$ adsorption. For the reactions, we find positive reaction orders with respect to $\mathrm{NO}$ and $\mathrm{O}_{2}$, whereas the reaction order with respect to $\mathrm{NH}_{3}$ is negative. The reaction orders and the obtained apparent activation energy are in good agreement with experimental data. A degree of rate

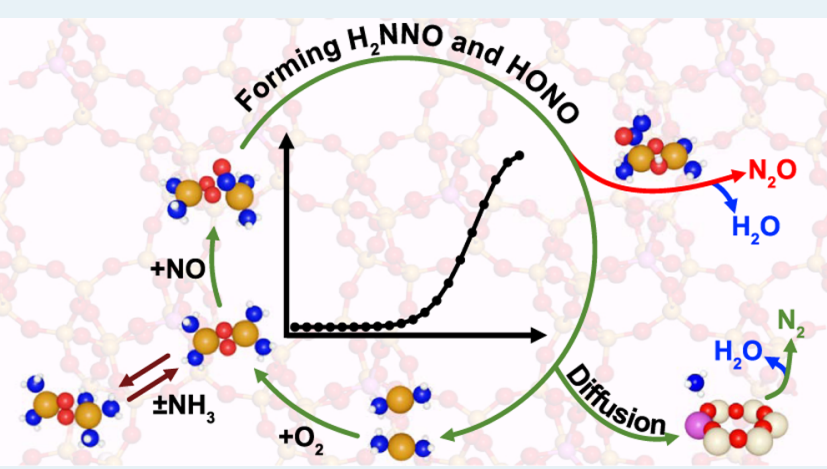
control analysis shows that $\mathrm{NH}_{3}$-SCR over a pair of $\mathrm{Cu}\left(\mathrm{NH}_{3}\right)_{2}{ }^{+}$is mainly controlled by $\mathrm{NO}$ adsorption below $200{ }^{\circ} \mathrm{C}$, whereas the formation of $\mathrm{HONO}$ and $\mathrm{H}_{2} \mathrm{NNO}$ becomes controlling at higher temperatures. The successful formulation of a first-principles microkinetic model for $\mathrm{NH}_{3}$-SCR rationalizes previous phenomenological models and links the kinetic behavior with materials properties, which results in unprecedented insights into the function of $\mathrm{Cu}-\mathrm{CHA}$ catalysts for $\mathrm{NH}_{3}-\mathrm{SCR}$.

KEYWORDS: first-principles microkinetic modeling, $\mathrm{Cu}$-CHA, $\mathrm{NH}_{3}-\mathrm{SCR}, \mathrm{N}_{2} \mathrm{O}$ formation, entropy evaluation

\section{INTRODUCTION}

Combustion in oxygen excess is energy-efficient but requires catalytic aftertreatment systems to control $\mathrm{NO}_{x}$ emissions. ${ }^{1}$ The current technology for lean-burn $\mathrm{NO}_{x}$ reduction is selective catalytic reduction (SCR) with ammonia as the reducing agent ( $\mathrm{NH}_{3}$-SCR), which reduces $\mathrm{NO}_{x}$ emissions efficiently. ${ }^{1}$ Catalysts based on $\mathrm{Cu}$-chabazite ( $\mathrm{Cu}-\mathrm{CHA}$ ) are common catalysts for $\mathrm{NH}_{3}$-SCR thanks to the low-temperature activity and good hydrothermal stability. ${ }^{1-3}$ The overall $\mathrm{NH}_{3}$-SCR reaction with only $\mathrm{NO}$ (standard SCR) is

$$
4 \mathrm{NH}_{3}+4 \mathrm{NO}+\mathrm{O}_{2} \rightarrow 4 \mathrm{~N}_{2}+6 \mathrm{H}_{2} \mathrm{O}
$$

This is a redox reaction that requires catalytic sites that can change oxidation state during the reaction, which for $\mathrm{Cu}$ means an alternation between $\mathrm{Cu}^{\mathrm{I}}$ and $\mathrm{Cu}{ }^{\mathrm{II}}$. The $\mathrm{NH}_{3}$-SCR reaction has been kinetically characterized by measurements of apparent activation energies and reaction orders. Under typical conditions for low-temperature $\mathrm{NH}_{3}$-SCR $\left(150-250{ }^{\circ} \mathrm{C}\right)$, the apparent activation energy for $\mathrm{NH}_{3}$-SCR has been reported to be in the range of $0.4-0.8 \mathrm{eV}^{4-6}$ The range in apparent activation energies can be ascribed to differences in $\mathrm{Cu}$ loading and presence of $\mathrm{H}_{2} \mathrm{O}$. The reaction order for $\mathrm{NO}$ conversion with respect to $\mathrm{O}_{2}$ has been measured to be between 0.2 and 0.5 , , 7 whereas the reaction order with respect to NO is $0.7-0.9$.,
Furthermore, the reaction order with respect to $\mathrm{NH}_{3}$ is zero or slightly negative when the $\mathrm{NH}_{3}$-to- $\mathrm{NO}_{x}$ ratio is close to $1^{4}$ indicating that $\mathrm{NH}_{3}$ inhibits the $\mathrm{NH}_{3}$-SCR reaction. The reaction order of $\mathrm{NH}_{3}$ depends on the $\mathrm{NH}_{3}$-to- $\mathrm{NO}_{x}$ ratio and has recently been measured to be positive at low $(0.1-0.5)$ ratios. $^{8}$

An unwanted side reaction during $\mathrm{NH}_{3}$-SCR is the partial reduction of $\mathrm{NO}$ to $\mathrm{N}_{2} \mathrm{O}$, which is a potent greenhouse gas receiving increasing attention. ${ }^{9}$ One proposed overall reaction for $\mathrm{N}_{2} \mathrm{O}$ formation is

$$
2 \mathrm{NH}_{3}+2 \mathrm{NO}+\mathrm{O}_{2} \rightarrow \mathrm{N}_{2}+\mathrm{N}_{2} \mathrm{O}+3 \mathrm{H}_{2} \mathrm{O}
$$

Different mechanistic reaction paths may exist for $\mathrm{N}_{2} \mathrm{O}$ formation, and $\mathrm{NH}_{4} \mathrm{NO}_{3}$ has been discussed as an intermediate at high temperatures (above $250{ }^{\circ} \mathrm{C}$ ). ${ }^{10-12}$ However, $\mathrm{N}_{2} \mathrm{O}$ is formed also at lower temperatures over $\mathrm{Cu}-\mathrm{CHA}$ and the $\mathrm{N}_{2} \mathrm{O}$ formation profile has been measured to follow that of $\mathrm{NH}_{3}$ -

Received: August 31, 2021

Revised: October 20, 2021

Published: November 15, 2021 
SCR. ${ }^{6,13}$ The apparent activation energy for low-temperature $\mathrm{N}_{2} \mathrm{O}$ formation has been measured to be $0.36 \mathrm{eV},{ }^{14}$ which is lower than the apparent activation energy for the $\mathrm{NH}_{3}-\mathrm{SCR}$ reaction.

In recent years, significant advances have been made in the understanding of the active sites and the reaction mechanism of low-temperature $\mathrm{NH}_{3}$-SCR reaction over $\mathrm{Cu}-\mathrm{CHA}$ catalyst. The current understanding is based on in situ X-ray absorption spectroscopy experiments in combination with density functional theory (DFT) calculations. It is now established that the ion-exchanged $\mathrm{Cu}$ does not occupy fixed positions in the zeolite during low-temperature operation but forms instead mobile $\mathrm{NH}_{3}$-solvated complexes. ${ }^{15-20}$

The adsorption of $\mathrm{O}_{2}$ is a key step in the reaction mechanism, which requires a pair of $\left[\mathrm{Cu}\left(\mathrm{NH}_{3}\right)_{2}\right]^{+}$complexes, forming $\left[\mathrm{Cu}_{2}\left(\mathrm{NH}_{3}\right)_{4} \mathrm{O}_{2}\right]^{2+}$ species. ${ }^{17,21-24}$ Activation of $\mathrm{O}_{2}$ induces the change in oxidation state of $\mathrm{Cu}$ from $\mathrm{Cu}^{\mathrm{I}}$ to $\mathrm{Cu}^{\mathrm{II}}$ (and possibly $\left.\mathrm{Cu}^{\mathrm{III}}\right),{ }^{25,26}$ which is known to be the active oxidation state for the subsequent $\mathrm{NH}_{3}$-assisted $\mathrm{NO}$ reduction. ${ }^{27}$ Two atomistic reaction cycles for low-temperature $\mathrm{NH}_{3}$-SCR involving [Cu$\left.\left(\mathrm{NH}_{3}\right)_{2}\right]^{+}$complexes and Brønsted acid sites were proposed recently based on density functional theory (DFT) calculation. ${ }^{18}$ The activation of oxygen and the formation of the key intermediates $\mathrm{HONO}$ and $\mathrm{H}_{2} \mathrm{NNO}$ were suggested to occur over the $\mathrm{Cu}$ sites, whereas the Brønsted acid sites facilitate the subsequent decomposition of $\mathrm{HONO}$ and $\mathrm{H}_{2} \mathrm{NNO}$ to $\mathrm{N}_{2}$ and $\mathrm{H}_{2} \mathrm{O}$. The two proposed cycles differ in the way $\mathrm{NO}$ is adsorbed on the $\left[\mathrm{Cu}_{2}\left(\mathrm{NH}_{3}\right)_{4} \mathrm{O}_{2}\right]^{2+}$ complex; $\mathrm{NO}$ adsorbs either on the $\mathrm{Cu}$ cation, forming nitrosonium $\left(\mathrm{NO}^{+}\right)$, or on an $\mathrm{O}$ atom forming a nitrite $\left(\mathrm{NO}_{2}{ }^{-}\right)$. The measured correlation between low-temperature $\mathrm{N}_{2}$ and $\mathrm{N}_{2} \mathrm{O}$ formation suggests a reaction path where $\mathrm{N}_{2} \mathrm{O}$ formation is connected to the $\mathrm{NH}_{3}$-SCR reaction cycle. We have recently presented a DFT-based mechanism for $\mathrm{H}_{2} \mathrm{NNO}$ decomposition into $\mathrm{N}_{2} \mathrm{O}$ and $\mathrm{H}_{2} \mathrm{O}$ over a $\left[\mathrm{Cu}_{2}\left(\mathrm{NH}_{3}\right)_{4} \mathrm{OOH}\right]^{2+}$ complex. ${ }^{12}$ The proposed reaction paths for $\mathrm{N}_{2}$ and $\mathrm{N}_{2} \mathrm{O}$ formation have flat potential energy landscapes, ${ }^{12,18}$ with the highest barriers related to the formation and decomposition of $\mathrm{H}_{2} \mathrm{NNO}$. However, these reaction mechanisms have not been evaluated by microkinetic modeling and their kinetic behaviors are presently unknown.

Phenomenological kinetic models have previously been developed for the $\mathrm{NH}_{3}$-SCR reaction over $\mathrm{Cu}-\mathrm{CHA}{ }^{14,28-31}$ These models generally treat the SCR reaction, $\mathrm{N}_{2} \mathrm{O}$ formation, and $\mathrm{NH}_{3}$ oxidation as global steps and consider schematic catalytic sites. For example, the model in ref 14 includes three catalytic sites, which are all associated with a combination of $\mathrm{Cu}$ and Brønsted acid sites. The formation of $\mathrm{N}_{2} \mathrm{O}$ is modeled with two reactions describing low- and high-temperature $\mathrm{N}_{2} \mathrm{O}$ formation, respectively. ${ }^{14}$ The phenomenological models are based on experimental data and describe accurately steady-state and transient kinetic behavior. However, because of the lumped sites and reaction steps, the models do not provide clear links between materials properties and catalytic performance.

Herein, we develop a first-principles-based microkinetic model for $\mathrm{NH}_{3}-\mathrm{SCR}$ over $\mathrm{Cu}-\mathrm{CHA}$, which is based on an extension of the previously proposed atomistic mechanisms for $\mathrm{N}_{2}$ and $\mathrm{N}_{2} \mathrm{O}$ formation. ${ }^{12,18}$ DFT calculations are used to obtain the potential energy surfaces and the reaction kinetics is treated in the mean-field approximation. The potential energy surfaces are flat, and the reaction rate depends sensitively on changes in the entropy. Thus, the evaluation of entropy changes along the reaction path is given special attention. The results from the kinetic model are in good agreement with our kinetic experiments of apparent activation energies, reaction orders, and $\mathrm{N}_{2} \mathrm{O}$ selectivity. The development of a successful firstprinciples-based microkinetic model for $\mathrm{NH}_{3}$-SCR over $\mathrm{Cu}$ $\mathrm{CHA}$ demonstrates the capability of first-principles kinetic models, rationalizes previous phenomenological kinetic models, and forms the basis for further improvement of $\mathrm{NH}_{3}-\mathrm{SCR}$ catalysts.

\section{COMPUTATIONAL AND EXPERIMENTAL METHODS}

First-Principles Calculation. Spin-polarized density functional theory calculations are performed with the Vienna $\mathrm{Ab}$ initio Simulation Package (VASP). ${ }^{32-35}$ The valence electrons are described with a plane-wave basis set using a cutoff energy of $480 \mathrm{eV}$, and the interaction between the valence and the core electrons is described with the projector augmented wave (PAW) method. ${ }^{36,37}$ The number of valence electrons treated in the calculations are $\mathrm{Cu}(11), \mathrm{Si}(4), \mathrm{Al}(3), \mathrm{O}(6), \mathrm{N}(5)$, and $\mathrm{H}(1)$. The $k$-point sampling is restricted to the $\Gamma$ point.

The gradient-corrected Perdew-Burke-Ernzerhof $(\mathrm{PBE})^{38}$ functional, augmented with a Hubbard- $U$ term and van der Waals corrections, is used to describe exchange-correlation effects. A Hubbard- $U$ term for $\mathrm{Cu} 3 \mathrm{~d}$ is needed to properly describe enzymatic systems ${ }^{39,40}$ with a similar $\mathrm{Cu}-\mathrm{OO}-\mathrm{Cu}$ core structure as the oxidized $\mathrm{Cu}$ species present during $\mathrm{NH}_{3}$ $\mathrm{SCR}$ over $\mathrm{Cu}-\mathrm{CHA}$. Here, we use a $U$-parameter of $6 \mathrm{eV}$ for $\mathrm{Cu}$ $3 \mathrm{~d}$, which has been determined by comparisons with the crystal structure of $\mathrm{Cu}_{2} \mathrm{O} .^{39}$ In addition, Grimme-D3 corrections have been applied to account for the van der Waals interactions of the molecules in the zeolites. 41,42

For the structure optimization, the convergence criterion in the self-consistent field (SCF) loop is set to $1 \times 10^{-5} \mathrm{eV}$ and the structures are considered to be relaxed when the force acting on each atom is less than $0.02 \mathrm{eV} / \AA$. Transition-state structures and activation energies are calculated using the climbing image nudged elastic band (CI-NEB) method. ${ }^{43,44}$ The transition-state structures are confirmed by vibrational analysis using the finite difference method. The search for low-energy structures is done by geometry-optimizing configurations obtained from BornOppenheimer $\mathrm{ab}$ initio molecular dynamics (AIMD) simulations, which are performed in the canonical (NVT) ensemble using a Nosé-Hoover thermostat. ${ }^{45,46}$

The chabazite structure is described in the rhombohedral unit cell, which contains 12 tetrahedral Si sites. The experimentally determined lattice parameters $\left(\alpha=\beta=\gamma=94.2^{\circ}, a=b=c=9.42\right.$ $\AA)$ are used and fixed during the structural optimizations. To model $\mathrm{Cu}$-exchanged $\mathrm{CHA}$, two $\mathrm{Si}$ atoms in the six-membered ring of the zeolite cages are replaced by $\mathrm{Al}$ yielding a $\mathrm{Si} / \mathrm{Al}$ ratio of 5 . This ratio is similar to common experimental values ${ }^{6,19,47}$ and, thus, is a reasonable choice when modeling the $\mathrm{Cu}-\mathrm{CHA}$ material for $\mathrm{NH}_{3}$-SCR. A structural model of the cabazite cages, with a $\left[\mathrm{Cu}_{2}\left(\mathrm{NH}_{3}\right)_{4} \mathrm{O}_{2}\right]^{2+}$ complex and the considered $\mathrm{Al}$ distribution, is shown in Figure 1. The CHA framework consists of large cages consisting of four-, six-, and eight-membered rings and small cages with four- and six-membered rings.

Microkinetic Modeling. Mean-field microkinetic modeling is used to simulate the reaction kinetics. The numerical solution of the equilibrium reaction rate and coverages are obtained by solving a set of coupled ordinary differential equations, which describe the time evolution of the adsorbate coverages. The differential equation for adsorbate $i$ is given by 
(a)

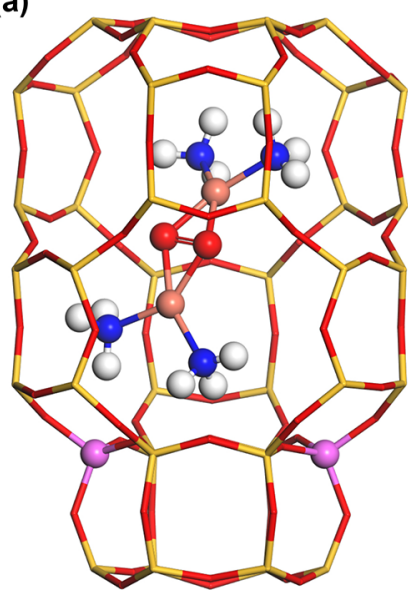

(b)

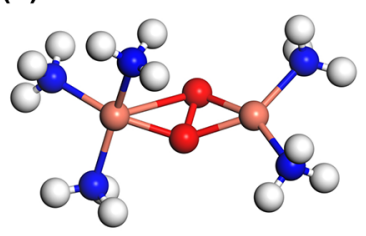

(c)

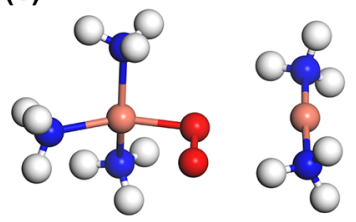

Figure 1. (a) Side view of the chabazite cages showing the $\mathrm{Al}$ positions in the six-membered ring. The large cage includes the $\left[\mathrm{Cu}_{2}\left(\mathrm{NH}_{3}\right)_{4}\left(\mathrm{O}_{2}\right)\right]^{2+}$ complex. (b, c) Two structures of $\left[\mathrm{Cu}_{2}\left(\mathrm{NH}_{3}\right)_{5}\left(\mathrm{O}_{2}\right)\right]^{2+}$. Atom color codes: $\mathrm{Cu}$ (bronze), $\mathrm{Si}$ (yellow), $\mathrm{Al}$ (pink), $\mathrm{O}$ (red), $\mathrm{N}$ (blue), and $\mathrm{H}$ (white).

$$
\frac{\mathrm{d} \theta_{i}}{\mathrm{~d} t}=\sum_{j} r_{j}(\vec{\theta}) c_{j i}
$$

where $\theta_{i}$ is the fractional coverage of species $i$ and $r_{j}$ is the rate of reaction $j$, which depends on the fractional coverages $(\vec{\theta})$. The number of $i$ molecules consumed in reaction $j$ is reflected in the stoichiometric number $\left(c_{j i}\right)$. The fractional coverage should in this case be understood as the fraction of $\mathrm{Cu}$ sites in the cycle being in a certain state. Thus, each state in the catalytic cycles represents a fractional coverage and the sum of all possible states is 1 . The physical structure, composition, and action of the $\mathrm{Cu}$ sites change in a sequential manner along the reaction cycle, and DFT calculations show that the states are mutually exclusive. In the absence of reactants, the metal adsorption site corresponds to two $\left[\mathrm{Cu}\left(\mathrm{NH}_{3}\right)\right]_{2}{ }^{+}$complexes, whereas the Brønsted acid site corresponds to $\mathrm{NH}_{4}{ }^{+}$. MATLAB is used with the ode23s solver to numerically integrate the system of differential equations until steady state is reached. The mean-field approach assumes a uniform sample with random distribution of reactants and intermediates. Thus, it is applicable in cases with $\mathrm{Cu} / \mathrm{Al}$ ratios where $\mathrm{Cu}$ - and Brønsted acid sites are spatially connected. The model assumes that $\mathrm{Cu}$-complex pairs form with high enough probability. The SCR rate has experimentally shown to scale linearly ${ }^{17}$ with $\mathrm{Cu}$ loadings above $0.1 \mathrm{Cu} / 1000 \AA^{3}$, and we anticipate that the model is valid for the $\mathrm{Cu}$ loadings in the linear regime.

The rate constants $k^{\mathrm{TST}}$ are computed according to the transition-state theory

$$
k^{\mathrm{TST}}=\frac{k_{\mathrm{B}} T}{h} \frac{Z^{\ddagger}}{Z}
$$

where $k_{\mathrm{B}}$ is the Boltzmann constant, $T$ is the temperature, $h$ is Planck's constant, $Z$ is the partition function of the initial state, and $Z^{\ddagger}$ is the partition function of the transition state without the reaction coordinate. In the transition state theory, the initial and transition states are assumed to be in equilibrium, which leads to the following expression for the rate constant ${ }^{48}$

$$
\begin{aligned}
& k^{\mathrm{TST}}=\frac{k_{\mathrm{B}} T}{h} \mathrm{e}^{-\Delta G^{\ddagger} / k_{\mathrm{B}} T}=\frac{k_{\mathrm{B}} T}{h} \mathrm{e}^{\Delta S^{\ddagger} / k_{\mathrm{B}}} \mathrm{e}^{-\Delta H^{\ddagger} / k_{\mathrm{B}} T} \\
& \approx \frac{k_{\mathrm{B}} T}{h} \mathrm{e}^{\Delta S^{\ddagger} / k_{\mathrm{B}}} \mathrm{e}^{-\Delta E^{\ddagger} / k_{\mathrm{B}} T}
\end{aligned}
$$

where $\Delta G^{\ddagger}$ is the difference in Gibbs free energy between the initial and transition states, and $\Delta S^{\ddagger}$ and $\Delta H^{\ddagger}$ are the corresponding differences in entropy and enthalpy, respectively. The $p V$ dependence on enthalpy is neglected and, hence, the change enthalpy becomes equal to the change in energy $\left(\Delta E^{\ddagger}\right)$.

The reaction energy barriers for adsorption steps are zero except for $\mathrm{O}_{2}$ adsorption, which has a low activation energy. All adsorption steps are, however, associated with entropy losses, which give rise to free energy barriers indicating that the rate constants are largely determined by entropy effects.

Evaluation of Entropy Changes. Because entropy effects contribute significantly to the values for the rate constants, special care is taken when evaluating the changes in entropy. The entropies for gas-phase molecules are, as usual, calculated via their vibrational, rotational, and translational partition functions, yielding

$$
S^{\text {gas }}=S_{\text {vib }}^{\text {gas }}+S_{\text {rot }}^{\text {gas }}+S_{\text {trans }}^{\text {gas }}
$$

Here, $S_{\text {vib }}^{\text {gas }}, S_{\text {rot }}^{\text {gas }}$, and $S_{\text {trans }}^{\text {gas }}$ are the vibrational, rotational, and translational entropies, respectively. It is generally challenging to describe changes in entropy during reactions in zeolites. ${ }^{4,50}$ For $\mathrm{NH}_{3}$-SCR in $\mathrm{Cu}-\mathrm{CHA}$, the challenge arises because some species are weakly bound and because the entropy of the adsorption site, i.e., $\left[\mathrm{Cu}\left(\mathrm{NH}_{3}\right)\right]_{2}^{+}$complexes, is lost upon $\mathrm{O}_{2}$ adsorption. Because of the different nature of the reactions along the reaction path, different approaches are required to describe the entropy changes.

In most cases, the harmonic approximation is used to evaluate the entropies of adsorbed species and transition states. However, in cases where the reactant enters the zeolite from the gas phase and is not chemically bound to the $\mathrm{Cu}$ complex, the translational and rotational entropies are estimated to be $2 / 3$ of the gas-phase values

$$
S^{\mathrm{zeo}}=S_{\mathrm{vib}}^{\mathrm{zeo}}+\frac{2}{3} \times\left(S_{\mathrm{rot}}^{\mathrm{gas}}+S_{\mathrm{trans}}^{\mathrm{gas}}\right)
$$

where $S_{\text {vib }}^{\text {zeo }}$ is the vibrational entropy calculated in the zeolite. This approach yields reasonable values for nonbound small molecules, such as $\mathrm{N}_{2}$ in zeolites. ${ }^{18,50}$

The entropy change upon $\mathrm{O}_{2}$ adsorption forming the $\left[\mathrm{Cu}_{2}\left(\mathrm{NH}_{3}\right)_{4} \mathrm{O}_{2}\right]_{2}^{+}$complex is a special case as both $\mathrm{O}_{2}$ and the $\left[\mathrm{Cu}\left(\mathrm{NH}_{3}\right)_{2}\right]^{+}$complexes lose entropy during the reaction. The entropies of $\left[\mathrm{Cu}\left(\mathrm{NH}_{3}\right)_{2}\right]^{+},\left[\mathrm{Cu}_{2}\left(\mathrm{NH}_{3}\right)_{4} \mathrm{O}_{2}\right]^{2+}$, and the transition state for $\mathrm{O}_{2}$ adsorption are calculated by scaling the values of the gas-phase complexes according to

$$
S^{\text {zeo }}=S_{\text {vib }}^{\text {zeo }}+0.29 \times\left(S_{\text {rot }}^{\text {gas }}+S_{\text {trans }}^{\text {gas }}\right)
$$

Here, the scaling of the rotational and translational entropies is reduced to 0.29 compared to the case with small molecules eq 5 . The decreased scaling is motivated by the larger sizes of the complexes, which hinders the rotational and translational motions, resulting in an additional reduction of the entropy. The value of 0.29 has been determined by fitting temperatureprogrammed desorption (TPD) profiles of $\mathrm{NH}_{3}$ from $[\mathrm{Cu}-$ $\left.\left(\mathrm{NH}_{3}\right)_{2}\right]^{+}$in Cu-CHA (see the Supporting Information (SI)). Using the scaling of $\left[\mathrm{Cu}\left(\mathrm{NH}_{3}\right)_{2}\right]^{+}$also for the $\left[\mathrm{Cu}_{2}\left(\mathrm{NH}_{3}\right)_{4} \mathrm{O}_{2}\right]^{2+}$ 


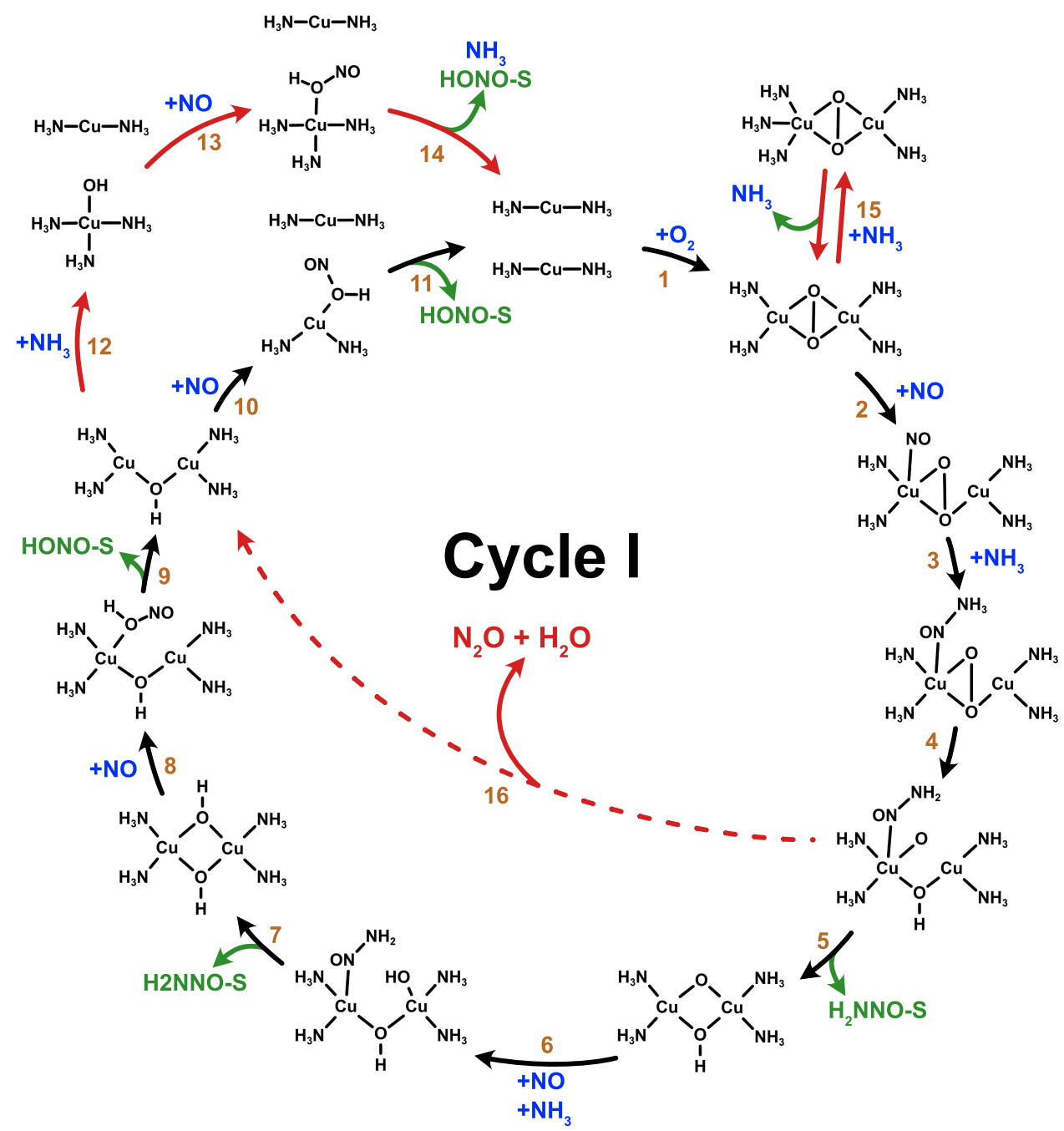

Figure 2. Proposed reaction cycle I for low-temperature $\mathrm{NH}_{3}$-SCR over $\mathrm{Cu}-\mathrm{CHA}$.

complex, the entropy differences of $\mathrm{O}_{2}$ adsorption in the forward reaction $\left(\Delta S_{\mathrm{f}}^{\text {zeo }}\right)$ and backward reaction $\left(\Delta S_{\mathrm{zeo}}^{\mathrm{b}}\right)$ are evaluated as

$$
\begin{aligned}
& \Delta S_{\mathrm{f}}^{\mathrm{zeo}}=S_{\mathrm{TS},\left[\mathrm{Cu}_{2}\left(\mathrm{NH}_{3}\right)_{4} \mathrm{O}_{2}\right]^{2+}}^{\mathrm{zeo}}-\left(2 S_{\left[\mathrm{Cu}\left(\mathrm{NH}_{3}\right)_{2}\right]^{+}}^{\mathrm{zeo}}+S_{\mathrm{O}_{2}}^{\text {gas }}\right) \\
& \Delta S_{\mathrm{b}}^{\mathrm{zeo}}=S_{\mathrm{TS},\left[\mathrm{Cu}_{2}\left(\mathrm{NH}_{3}\right)_{4} \mathrm{O}_{2}\right]^{2+}}^{\mathrm{zeo}}-S_{\left[\mathrm{Cu}_{2}\left(\mathrm{NH}_{3}\right)_{4} \mathrm{O}_{2}\right]^{2+}}^{\mathrm{zeo}}
\end{aligned}
$$

where $S_{\mathrm{TS},\left[\mathrm{Cu}_{2}\left(\mathrm{NH}_{3}\right)_{4} \mathrm{O}_{2}\right]^{2+}}^{\mathrm{zeo}}$ and $S_{\left[\mathrm{Cu}_{2}\left(\mathrm{NH}_{3}\right)_{4} \mathrm{O}_{2}\right]^{2+}}^{\mathrm{zeo}}$ are the entropies of the transition- and final-state configurations, respectively. $S_{\left[\mathrm{Cu}\left(\mathrm{NH}_{3}\right)_{2}\right]^{+}}^{\mathrm{zeo}}$ is the entropy of the $\left[\mathrm{Cu}\left(\mathrm{NH}_{3}\right)_{2}\right]^{+}$complex in the zeolite. The experimentally determined value of the entropy loss for $\mathrm{O}_{2}$ adsorption on a pair of $\left[\mathrm{Cu}\left(\mathrm{NH}_{3}\right)_{2}\right]^{+}$complexes was recently reported to be $142 \mathrm{~J} /(\mathrm{mol} \cdot \mathrm{K}),{ }^{24}$ which is close to our computational estimate of $152 \mathrm{~J} /(\mathrm{mol} \cdot \mathrm{K})$. The good agreement between computed and measured entropy changes further validates the gas-phase scaling in eq 6 .

Experimental Methods. Sample Preparation. The $\mathrm{Cu}-$ $\mathrm{CHA}$ catalysts were prepared from the same parent $\mathrm{H}-\mathrm{CHA}$ material ( $\mathrm{Si} / \mathrm{Al}$ ratio 6.7), via impregnation with an aqueous solution of $\mathrm{Cu}$ nitrate. The $\mathrm{Cu}$ content in the $\mathrm{Cu}-\mathrm{CHA}$ catalysts was varied to 1.6 and $3.2 \mathrm{wt} \%$ by an adjustment of the $\mathrm{Cu}$ nitrate concentration in the impregnation liquid. The impregnated catalysts were dried at $100^{\circ} \mathrm{C}$ and calcined in air at $500^{\circ} \mathrm{C}$ for 2 h.
Kinetic Measurements. The reaction order measurements are carried out in a flow reactor with $1.6 \mathrm{wt} \% \mathrm{Cu}-\mathrm{CHA}$. The experimental setup consists of a gas mixing system, which includes mass flow controllers (Bronkhorst Hi-Tech), a powder reactor (Setaram Sensys DSC) with a vertically mounted quartz tube (inner diameter $4 \mathrm{~mm}$ ), and a mass spectrometer (Airsense Compact, V\&F). Cu-CHA sample (11.3 mg, 1.6 wt \%) (sieve fraction $300-355 \mu \mathrm{m}$ ) is placed on a sintered quartz bed in the quartz tube. The total gas flow is $300 \mathrm{NmL} / \mathrm{min}$, and the reaction temperature is $200{ }^{\circ} \mathrm{C}$. The sample is pretreated in $\mathrm{O}_{2}$ at $500{ }^{\circ} \mathrm{C}$ for $30 \mathrm{~min}$ prior to the kinetic measurements. For the reaction order measurements with respect to $\mathrm{NO}$, the concentrations of $\mathrm{NH}_{3}$ and $\mathrm{O}_{2}$ are held constant at $843 \mathrm{ppm}$ and $10.3 \%$, respectively. The NO concentration is varied from 88 to $722 \mathrm{ppm}$. In the measurement for the reaction order with respect to $\mathrm{NH}_{3}$, the $\mathrm{NO}$ concentration and $\mathrm{O}_{2}$ concentrations are $109 \mathrm{ppm}$ and $10.3 \%$, respectively, and the $\mathrm{NH}_{3}$ concentration is varied between 190 and 1009 ppm. Finally, the concentration of $\mathrm{O}_{2}$ is varied from 1.1 to $10.3 \%$ in a mixture of $381 \mathrm{ppm} \mathrm{NO}$ and $641 \mathrm{ppm} \mathrm{NH}_{3}$, to measure the reaction order with respect to $\mathrm{O}_{2}$. The reaction conditions are maintained for at least $20 \mathrm{~min}$ for each concentration, allowing the reaction to reach steady state. Ar is used as balance in all measurements. 


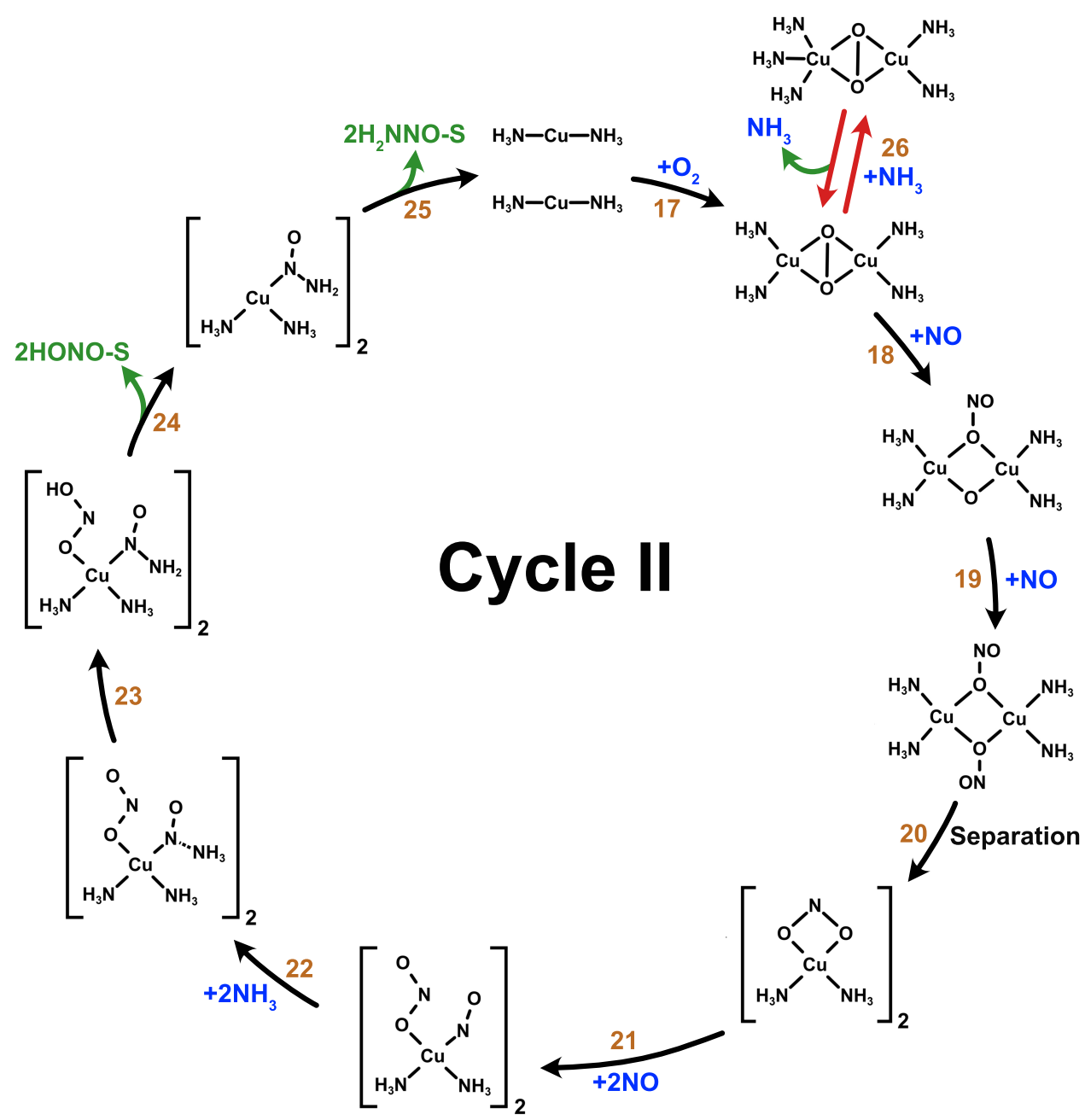

Figure 3. Proposed reaction cycle II for low-temperature $\mathrm{NH}_{3}$-SCR over $\mathrm{Cu}-\mathrm{CHA}$.

The conversion profiles for $\mathrm{NO}_{x}$ conversion are measured in a different powder reactor setup, using $10 \mathrm{mg}$ of catalyst sample in a quartz U-tube reactor (inner diameter $4 \mathrm{~mm}$, sieve fraction 150-300 $\mu \mathrm{m}$ ), using a feed gas consisting of $500 \mathrm{ppm} \mathrm{NO}, 600$ ppm $\mathrm{NH}_{3}, 10 \% \mathrm{O}_{2}$ in $\mathrm{N}_{2}$, at a flow rate of $300 \mathrm{NmL} / \mathrm{min}$. A Gasmet CX4000 Fourier transform infrared (FTIR) spectrometer is used to monitor the gas composition of the reactor exit gas and the feed gas by bypassing the reactor. Prior to the measurement, the sample is heated to $550{ }^{\circ} \mathrm{C}$, in $10 \% \mathrm{O}_{2}$ in $\mathrm{N}_{2}$ for 30 min, after which the feed gas is admitted to the reactor. The catalyst is then cooled down stepwise to $150{ }^{\circ} \mathrm{C}$, and for each data point, the temperature is kept constant for $30 \mathrm{~min}$.

\section{RESULTS}

Catalytic Cycles and Elementary Reactions. The microkinetic models are based on the catalytic cycles for $\mathrm{NH}_{3}$ SCR of $\mathrm{NO}$ to $\mathrm{N}_{2}$ and $\mathrm{H}_{2} \mathrm{O}$ together with $\mathrm{N}_{2} \mathrm{O}$ formation shown in Figures 2-4. The cycles are further developments (marked by red arrows in Figures 2 and 3 ) of the multisite reaction mechanism suggested in ref 18 . The mechanisms consist of two reaction cycles that combine the formation of $\mathrm{HONO}$ and $\mathrm{H}_{2} \mathrm{NNO}$ intermediates at the $\mathrm{Cu}$ sites with the decomposition of these intermediates to $\mathrm{N}_{2}$ and $\mathrm{H}_{2} \mathrm{O}$ over Brønsted acid sites. A common step for both cycles is $\mathrm{O}_{2}$ adsorption on a pair of $\left[\mathrm{Cu}\left(\mathrm{NH}_{3}\right)_{2}\right]^{+}$complexes. A necessary condition to adsorb $\mathrm{O}_{2}$ is to have two $\left[\mathrm{Cu}\left(\mathrm{NH}_{3}\right)_{2}\right]^{+}$complexes located in the same zeolite cage. The diffusion barrier of the complexes in CHA is small, ${ }^{17,51}$ and the probability of having two complexes in the same cage is determined by the relative stability of paired and separated complexes. Based on the literature, ${ }^{17,52}$ we estimate the relative stability of having two complexes in the same cage to be $0.3 \mathrm{eV}$ lower than having complexes in different cages. The relative stability depends on the aluminum distribution together with how far the complexes are from the original $\mathrm{Al}$ site and could vary by some $0.1 \mathrm{eV}$. The chosen relative stability corresponds to a probability of $6 \times 10^{-4}$ having two complexes in the same cage. Assuming two complexes in the same cage, the reaction cycle starts with the $\mathrm{O}_{2}$ adsorption step (reactions $\mathrm{r} 1$ and $\mathrm{r} 17$ ), when a $\left[\mathrm{Cu}_{2}\left(\mathrm{NH}_{3}\right)_{4} \mathrm{O}_{2}\right]^{2+}$ complex is formed, denoted by *-OO-*, where $*$ represents $\left[\mathrm{Cu}\left(\mathrm{NH}_{3}\right)_{2}\right]^{+}$. The adsorption of $\mathrm{O}_{2}$ has a low energy barrier of $0.13 \mathrm{eV}$ and is calculated to be exothermic by $0.20 \mathrm{eV}$. The two cycles follow different paths after the $\mathrm{O}_{2}$ adsorption.

In cycle I (Figure 2), NO adsorbs on a Cu cation (reaction $\mathrm{r} 2$ ) forming $\mathrm{NO}-\mathrm{OO}-*$. An additional $\mathrm{NH}_{3}$ molecule coordinates to $\mathrm{NO}-\mathrm{OO}-*$ (reaction $\mathrm{r} 3$ ) and reacts (reaction $\mathrm{r} 4$ ) forming $\mathrm{H}_{2} \mathrm{NNO}-\mathrm{OOH}-*$. $\mathrm{H}_{2} \mathrm{NNO}$ desorbs from the $\mathrm{Cu}$ site (reaction r5) and diffuses to a Brønsted acid site (denoted by S). The reaction proceeds by subsequent $\mathrm{NO}$ and $\mathrm{NH}_{3}$ adsorption and the formation of $\mathrm{H}_{2} \mathrm{NNO}-\mathrm{OH}-\mathrm{OH}$. The second $\mathrm{H}_{2} \mathrm{NNO}$ desorbs from the $\mathrm{Cu}$ site and diffuses to the Brønsted acid site (reaction $\mathrm{r} 7$ ), which allows adsorption of the third NO in the 


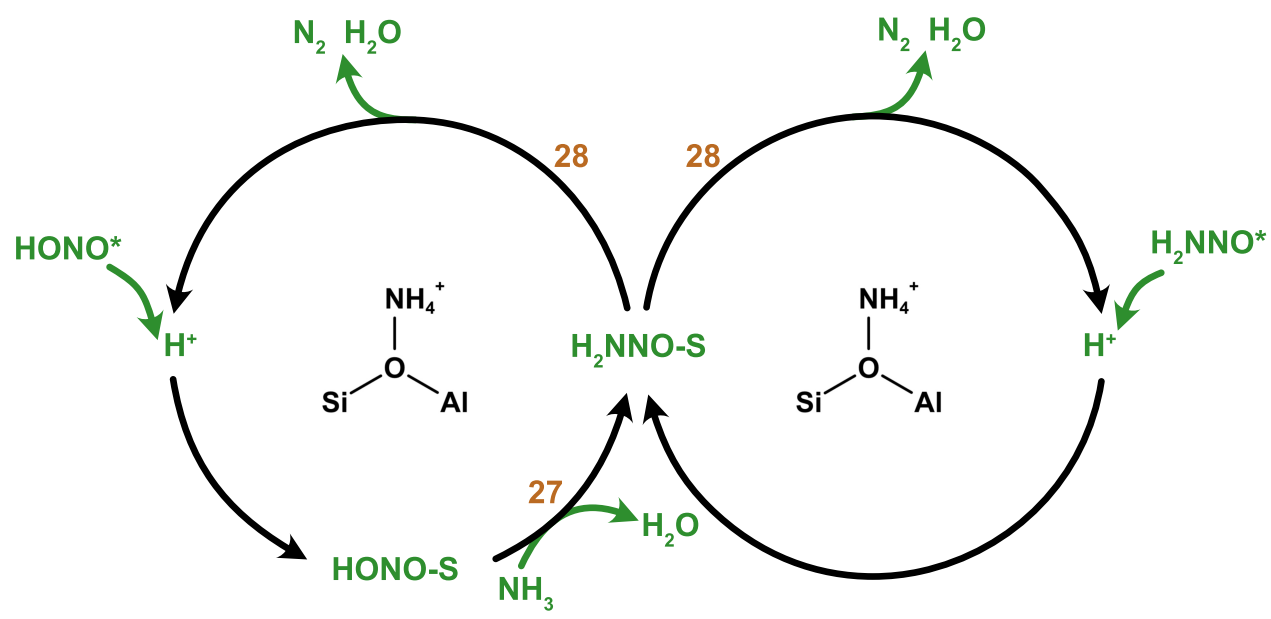

Figure 4. Proposed reaction path for $\mathrm{HONO}$ and $\mathrm{H}_{2} \mathrm{NNO}$ decomposition over Brønsted acid sites.

reaction cycle (reaction $\mathrm{r} 8$ ) forming $\mathrm{HONO}-\mathrm{OH}-*$. $\mathrm{HONO}$ desorbs (reaction $\mathrm{r} 9$ ) and reacts further over a Brønsted acid site. Once HONO desorbs, the remaining $*-\mathrm{OH}-*$ can react with $\mathrm{NO}$ to produce a second HONO (reactions r10 and r11). One alternative reaction path is adsorption of an additional $\mathrm{NH}_{3}$, forming $\mathrm{NH}_{3}-\mathrm{OH}-*$ and * (reaction r12). NO can adsorb on $\mathrm{NH}_{3}-\mathrm{OH}-*$, forming HONO (reaction r13), which desorbs and diffuses to a Brønsted acid site in reaction $\mathrm{r} 14$. In reaction $\mathrm{r} 14$, the additional $\mathrm{NH}_{3}$ desorbs and the second linear $\left[\mathrm{Cu}\left(\mathrm{NH}_{3}\right)_{2}\right]^{+}$complex is restored.

The presence of $*-\mathrm{OO}-*$ is crucial as it allows for $\mathrm{NO}$ adsorption. However, $\mathrm{NH}_{3}$ can also adsorb on *-OO-*, which was not considered in ref 18 . Possible structures for $\mathrm{NH}_{3}$ adsorption onto $*-\mathrm{OO}-*$ are shown in Figure 1b,c. The adsorption energy of $\mathrm{NH}_{3}$ is in structure (b) $-0.98 \mathrm{eV}$, which is larger than the adsorption energy for $\mathrm{NO}$, being $-0.70 \mathrm{eV}$. An alternative structure is shown in Figure 1c, where the two $\mathrm{Cu}$ complexes are separated and $\mathrm{O}_{2}$ is bound to only one $\mathrm{Cu}$ atom. In this case, the adsorption energy is $-0.94 \mathrm{eV}$. Structures (b) and (c) are separated by a barrier of $0.33 \mathrm{eV}$. The possibility for $\mathrm{NH}_{3}$ to adsorb on the *-OO-* complex has recently been observed experimentally with X-ray absorption spectroscopy, which was assigned to be a structure similar to $(c) .{ }^{22}$ We include (b) in the reaction cycle (reaction $\mathrm{r} 15$ ) as a lumped configuration describing both (b) and (c). After the adsorption of the additional $\mathrm{NH}_{3}$ on $*-\mathrm{OO}-*$, NO cannot adsorb on that complex, which implies that $\mathrm{NH}_{3}$ adsorption blocks the site for further reactions.

In our recent work, we proposed a possible path for $\mathrm{N}_{2} \mathrm{O}$ formation within cycle I. ${ }^{12} \mathrm{~N}_{2} \mathrm{O}$ may form as a side reaction by direct decomposition of $\mathrm{H}_{2} \mathrm{NNO}$ over $\mathrm{H}_{2} \mathrm{NNO}-\mathrm{OOH}-*$. Once $\mathrm{H}_{2} \mathrm{NNO}-\mathrm{OOH}-*$ is formed after reaction $\mathrm{r} 4$, it is possible for $\mathrm{H}_{2} \mathrm{NNO}$ to transfer two $\mathrm{H}$ atoms to the $\mathrm{OOH}-*$ intermediate (reaction r16) rather than to diffuse to the Brønsted acid sites (reaction $\mathrm{r} 5$ ). The decomposition of $\mathrm{H}_{2} \mathrm{NNO}$ into $\mathrm{N}_{2} \mathrm{O}$ and $\mathrm{H}_{2} \mathrm{O}$ is associated with a barrier of $0.40 \mathrm{eV}$ (see Figure S3 in the Supporting Information).

Turning to cycle II (Figure 3 ), each O site of *-OO-* will adsorb one NO forming -ONOONO- (reactions r18 and r19). The complex separates into two ONO- (reaction r20) describing adsorbed nitrites $\left(\mathrm{NO}_{2}{ }^{-}\right)$. The separated complexes react subsequently with $\mathrm{NO}$ (reaction $\mathrm{r} 21$ ) and $\mathrm{NH}_{3}$ (reaction r22) forming $\mathrm{HONO}-\mathrm{H}_{2} \mathrm{NNO}$ (reaction r23). $\mathrm{HONO}$ and $\mathrm{H}_{2} \mathrm{NNO}$ desorb (reactions $\mathrm{r} 24$ and r25) and decompose into $\mathrm{N}_{2}$ and $\mathrm{H}_{2} \mathrm{O}$ at the Brønsted acid sites. At this point, the $\mathrm{Cu}$ sites are restored as linear complexes *. Similar to cycle $\mathrm{I}, \mathrm{NH}_{3}$ may adsorb on *-OO-* (reaction $\mathrm{r} 26$ ) and hinder $\mathrm{NO}$ adsorption. We do not consider $\mathrm{N}_{2} \mathrm{O}$ formation in cycle II as $\mathrm{H}_{2} \mathrm{NNO}$ cannot decompose by hydrogen transfers in this cycle.

The $\mathrm{H}_{2} \mathrm{NNO}$ and $\mathrm{HONO}$ species that are generated over the $\mathrm{Cu}$ complexes in cycles I and II diffuse to the Brønsted acid sites and decompose into $\mathrm{N}_{2}$ and $\mathrm{H}_{2} \mathrm{O}$. The paths for $\mathrm{HONO}$ and $\mathrm{H}_{2} \mathrm{NNO}$ decomposition are shown in Figure 4, where $\mathrm{S}$ denotes a Brønsted acid site. Because $\mathrm{NH}_{3}$ is strongly adsorbed on the Brønsted acid sites, the decomposition of $\mathrm{H}_{2} \mathrm{NNO}$ and $\mathrm{HONO}$ occurs over $\mathrm{NH}_{4}{ }^{+}$. The HONO species reacts with an additional $\mathrm{NH}_{3}$ (reaction r27) forming $\mathrm{H}_{2} \mathrm{O}$ and $\mathrm{H}_{2} \mathrm{NNO}-\mathrm{S}$, which together with $\mathrm{H}_{2} \mathrm{NNO}$ from the $\mathrm{Cu}$ site can decompose into $\mathrm{N}_{2}$ and $\mathrm{H}_{2} \mathrm{O}$ (reaction r28). The mechanisms of $\mathrm{H}_{2} \mathrm{NNO}$ and HONO decomposition over Brønsted acid site have previously been discussed by us ${ }^{18}$ and are similar to those reported by Li et al. $^{53}$

It is important to note that the reaction cycles contain four types of $\mathrm{NH}_{3}$, with different roles in the low-temperature $\mathrm{NH}_{3}-$ SCR reaction:

1. Ligand- $\mathrm{NH}_{3}: \mathrm{NH}_{3}$ that adsorbs on the $\mathrm{Cu}$ cations, forming mobile $\left[\mathrm{Cu}\left(\mathrm{NH}_{3}\right)_{2}\right]^{+}$complexes, which enable facile formation of pairs for $\mathrm{O}_{2}$ adsorption. The ligand$\mathrm{NH}_{3}$ does not participate in the low-temperature SCR reaction provided that $\mathrm{NH}_{3}$ is in excess.

2. Inhibiting $\mathrm{NH}_{3}: \mathrm{NH}_{3}$ that adsorbs strongly on the $\left[\mathrm{Cu}_{2}\left(\mathrm{NH}_{3}\right)_{4} \mathrm{O}_{2}\right]^{2+}$ species, and thereby blocks the adsorption of $\mathrm{NO}$, which is required for $\mathrm{NH}_{3}$ SCR reaction.

3. Reactant- $\mathrm{NH}_{3}: \mathrm{NH}_{3}$ that takes part in the reaction by reacting with $\mathrm{NO}$.

4. $\mathrm{NH}_{4}^{+}: \mathrm{NH}_{3}$ that is adsorbed at the Brønsted acid sites forming $\mathrm{NH}_{4}{ }^{+}$.

This means that, in low-temperature $\mathrm{NH}_{3}$-SCR, $\mathrm{NH}_{3}$ acts simultaneously as reactant, spectator, and inhibitor.

Kinetics for $\mathrm{NH}_{3}-\mathrm{SCR}$ and $\mathrm{N}_{2} \mathrm{O}$ Formation. The atomistic reaction cycles form the basis of the microkinetic model. The elementary reactions included in the microkinetic models together with the corresponding enthalpy and entropy barriers are given in Table 1 . The corresponding electronic energy landscapes are shown in Figures S1 and S2 in the Supporting Information. The enthalpies for the main SCR cycles and the $\mathrm{N}_{2} \mathrm{O}$ formation are taken from refs 12 and 18, respectively. The 
Table 1. Energy $\left(\Delta E^{\ddagger}\right)$ and Entropy $\left(\Delta S^{\ddagger}\right)$ Contributions to the Reaction Barriers of the Considered Elementary Steps ${ }^{a}$

\begin{tabular}{|c|c|c|c|c|c|}
\hline no. & elementary step & $\Delta E_{\mathrm{f}}^{\dagger}$ & $\Delta E_{\mathrm{b}}^{\ddagger}$ & $\Delta S_{f}^{\ddagger}$ & $\Delta S_{\mathrm{b}}^{ \pm}$ \\
\hline \multicolumn{6}{|c|}{$\mathrm{Cu}-$ Cycle I } \\
\hline & $\mathrm{O}_{2}+2 * \stackrel{\mathrm{r}_{1}}{\leftrightarrow} *-\mathrm{OO}-*$ & 0.13 & 0.33 & -134.9 & 17.6 \\
\hline $\mathrm{r} 1$ & $\mathrm{O}_{2}+2 * \stackrel{\mathrm{r}_{1}}{\leftrightarrow} *-\mathrm{OO}-*(\exp \cdot \Delta E) \quad(\mathrm{r} 1)$ & 0.13 & 0.95 & -134.9 & 17.6 \\
\hline $\mathrm{r} 2$ & $\mathrm{NO}+*-\mathrm{OO}-* \stackrel{\mathrm{r}_{2}}{\leftrightarrow} \mathrm{NO}-\mathrm{OO}-* \quad(\mathrm{r} 2)$ & 0.00 & 0.70 & -109.2 & 0.0 \\
\hline r3 & $\mathrm{NH}_{3}+\mathrm{NO}-\mathrm{OO}-* \stackrel{\mathrm{r}_{3}}{\leftrightarrow} \mathrm{NH}_{3} \mathrm{NO}-\mathrm{OO}-* \quad(\mathrm{r} 3)$ & 0.00 & 0.31 & -65.6 & 0.0 \\
\hline r4 & $\mathrm{NH}_{3} \mathrm{NO}-\mathrm{OO}-* \stackrel{\mathrm{r}_{4}}{\leftrightarrow} \mathrm{H}_{2} \mathrm{NNO}-\mathrm{OOH}-* \quad(\mathrm{r} 4)$ & 0.05 & 0.54 & -2.5 & -44.4 \\
\hline r5 & $\mathrm{H}_{2} \mathrm{NNO}-\mathrm{OOH}-*+\mathrm{S} \stackrel{\mathrm{r}_{5}}{\leftrightarrow} \mathrm{H}_{2} \mathrm{NNO}-\mathrm{S}+*-\mathrm{OHO}-* \quad(\mathrm{r} 5)$ & 0.30 & 0.60 & 0.0 & 0.0 \\
\hline r6 & $\mathrm{NO}+\mathrm{NH}_{3}+*-\mathrm{OHO}-* \stackrel{\mathrm{r}_{6}}{\leftrightarrow} \mathrm{H}_{2} \mathrm{NNO}-\mathrm{OH}-\mathrm{OH} \quad(\mathrm{r} 6)$ & 0.16 & 0.60 & -3.2 & 38.8 \\
\hline r7 & $\mathrm{H}_{2} \mathrm{NNO}-\mathrm{OH}-\mathrm{OH}+\mathrm{S} \stackrel{\mathrm{r}_{7}}{\leftrightarrow} \mathrm{H}_{2} \mathrm{NNO}-\mathrm{S}+*-\mathrm{OHOH}-* \quad(\mathrm{r} 7)$ & 0.30 & 0.60 & 0.0 & 0.0 \\
\hline r8 & $\mathrm{NO}+*-\mathrm{OHOH}-* \stackrel{\mathrm{r}_{8}}{\leftrightarrow} \mathrm{HONO}-\mathrm{OH}-* \quad(\mathrm{r} 8)$ & 0.10 & 0.39 & -120.9 & 0.0 \\
\hline r9 & $\mathrm{HONO}-\mathrm{OH}-*+\mathrm{S} \stackrel{\mathrm{r}_{9}}{\leftrightarrow} \mathrm{HONO}-\mathrm{S}+*-\mathrm{OH}-* \quad(\mathrm{r} 9)$ & 0.30 & 0.60 & 0.0 & 0.0 \\
\hline $\mathrm{r} 10$ & $\mathrm{NO}+*-\mathrm{OH}-* \stackrel{\mathrm{r}_{10}}{\leftrightarrow}[\mathrm{HONO}-*+*] \quad(\mathrm{r} 10)$ & 0.10 & 1.03 & -120.9 & 0.0 \\
\hline r11 & {$[\mathrm{HONO}-*+*]+\mathrm{S} \stackrel{\mathrm{r}_{11}}{\leftrightarrow} \mathrm{HONO}-\mathrm{S}+2^{*} \quad(\mathrm{r} 11)$} & 0.30 & 0.60 & 0.0 & 0.0 \\
\hline $\mathrm{r} 12$ & $\mathrm{NH}_{3}+*-\mathrm{OH}-* \stackrel{\mathrm{r}_{12}}{\leftrightarrow}\left[\mathrm{NH}_{3}-\mathrm{OH}-*+*\right] \quad(\mathrm{r} 12)$ & 0.00 & 0.97 & -90.4 & 0.0 \\
\hline r13 & $\mathrm{NO}+\left[\mathrm{NH}_{3}-\mathrm{OH}-*+*\right] \stackrel{\mathrm{r}_{13}}{\leftrightarrow}\left[\mathrm{HONO}-\mathrm{NH}_{3}-*+*\right] \quad(\mathrm{r} 13)$ & 0.00 & 0.32 & -120.9 & 0.0 \\
\hline r14 & {$\left[\mathrm{HONO}-\mathrm{NH}_{3}-*+*\right]+\mathrm{S} \stackrel{\mathrm{r}_{14}}{\leftrightarrow} \mathrm{NH}_{3}+\mathrm{HONO}-\mathrm{S}+2^{*} \quad(\mathrm{r} 14)$} & 0.30 & 0.60 & 90.4 & 0.0 \\
\hline r15 & $\mathrm{NH}_{3}+*-\mathrm{OO}-* \stackrel{\mathrm{r}_{15}}{\leftrightarrow} \mathrm{NH}_{3}-\mathrm{OO}-* \quad(\mathrm{r} 15)$ & 0.00 & 0.98 & -103.8 & 0.0 \\
\hline r16 & $\mathrm{H}_{2} \mathrm{NNO}-\mathrm{OOH}-* \stackrel{\mathrm{r}_{16}}{\leftrightarrow} \mathrm{N}_{2} \mathrm{O}+\mathrm{H}_{2} \mathrm{O}+*-\mathrm{OH}-* \quad(\mathrm{r} 16)$ & 0.40 & 2.61 & 2.7 & -301.4 \\
\hline \multicolumn{6}{|c|}{$\mathrm{Cu}-$ Cycle II } \\
\hline r17 & $\mathrm{O}_{2}+2 * \stackrel{\mathrm{r}_{17}}{\leftrightarrow} *-\mathrm{OO}-*(\exp \cdot \Delta E) \quad(\mathrm{r} 17)$ & 0.13 & 0.95 & -134.9 & 17.6 \\
\hline $\mathrm{r} 18$ & $\mathrm{NO}+*-\mathrm{OO}-* \stackrel{\mathrm{r}_{18}}{\leftrightarrow}-\mathrm{ONOO}-* \quad(\mathrm{r} 18)$ & 0.00 & 1.65 & -143.4 & 0.0 \\
\hline r19 & $\mathrm{NO}+-\mathrm{ONOO}-* \stackrel{\mathrm{r}_{19}}{\leftrightarrow}-\mathrm{ONOONO}-\quad(\mathrm{r} 19)$ & 0.00 & 1.65 & -143.4 & 0.0 \\
\hline $\mathrm{r} 20$ & $-\mathrm{ONOONO}-\stackrel{\mathrm{r}_{20}}{\leftrightarrow} 2 \mathrm{ONO}-\quad(\mathrm{r} 20)$ & 0.37 & 0.40 & -41.5 & -7.4 \\
\hline $\mathrm{r} 21$ & $\mathrm{NO}+\mathrm{ONO}-\stackrel{\mathrm{r}_{21}}{\leftrightarrow} \mathrm{ONO}-\mathrm{NO} \quad(\mathrm{r} 21)$ & 0.00 & 0.91 & -132.3 & 0.0 \\
\hline $\mathrm{r} 22$ & $\mathrm{NH}_{3}+\mathrm{ONO}-\mathrm{NO} \stackrel{\mathrm{r}_{22}}{\leftrightarrow} \mathrm{ONO}-\mathrm{NONH}_{3} \quad(\mathrm{r} 22)$ & 0.00 & 0.67 & -65.6 & 0.0 \\
\hline $\mathrm{r} 23$ & $\mathrm{ONO}-\mathrm{NONH}_{3} \stackrel{\mathrm{r}_{23}}{\leftrightarrow} \mathrm{HONO}-\mathrm{H}_{2} \mathrm{NNO} \quad(\mathrm{r} 23)$ & 0.62 & 0.80 & -14.6 & 12.5 \\
\hline $\mathrm{r} 24$ & $\mathrm{HONO}-\mathrm{H}_{2} \mathrm{NNO}+\mathrm{S} \stackrel{\mathrm{r}_{24}}{\leftrightarrow} \mathrm{H}_{2} \mathrm{NNO}-*+\mathrm{HONO}-\mathrm{S} \quad(\mathrm{r} 24)$ & 0.30 & 0.60 & 0.0 & 0.0 \\
\hline $\mathrm{r} 25$ & $\mathrm{H}_{2} \mathrm{NNO}-*+\mathrm{S} \stackrel{\mathrm{r}_{25}}{\leftrightarrow} \mathrm{H}_{2} \mathrm{NNO}-\mathrm{S}+* \quad(\mathrm{r} 25)$ & 0.30 & 0.60 & 0.0 & 0.0 \\
\hline $\mathrm{r} 26$ & $\mathrm{NH}_{3}+*-\mathrm{OO}-* \stackrel{\mathrm{r}_{26} 6}{\leftrightarrow} \mathrm{NH}_{3}-\mathrm{OO}-* \quad(\mathrm{r} 26)$ & 0.00 & 0.98 & -103.8 & 0.0 \\
\hline \multicolumn{6}{|c|}{ Brønsted Acid Site } \\
\hline $\mathrm{r} 27$ & $\mathrm{NH}_{3}+\mathrm{HONO}-\mathrm{S} \stackrel{\mathrm{r}_{27}}{\leftrightarrow} \mathrm{H}_{2} \mathrm{NNO}-\mathrm{S}+\mathrm{H}_{2} \mathrm{O} \quad(\mathrm{r} 27)$ & 0.38 & 0.93 & 19.7 & -194.6 \\
\hline $\mathrm{r} 28$ & $\mathrm{H}_{2} \mathrm{NNO}-\mathrm{S} \stackrel{\mathrm{r}_{28}}{\leftrightarrow} \mathrm{H}_{2} \mathrm{O}+\mathrm{N}_{2}+\mathrm{S} \quad(\mathrm{r} 28)$ & 0.38 & 2.08 & -70.1 & -294.4 \\
\hline
\end{tabular}

${ }^{a}$ Reaction $\mathrm{r} 20$ involves the separation of the paired linear complexes, resulting in the stoichiometric 2 on the product side. Reactions r $21-\mathrm{r} 25$ are in the simulations doubled to account for two parallel reactions on separated complexes. Energy is given in eV and entropy in $\mathrm{J} /(\mathrm{mol} \cdot \mathrm{K})$. The $*$ and $\mathrm{S}$ in the elementary steps represent one $\left[\mathrm{Cu}\left(\mathrm{NH}_{3}\right)_{2}\right]^{+}$complex and one $\mathrm{NH}_{4}{ }^{+}$, respectively.

two cycles are decoupled in the simulations. The enthalpy barriers including zero-point corrections are evaluated using DFT as discussed above with the exception of $\mathrm{O}_{2}$ adsorption. In the kinetic simulations, the adsorption energy of $\mathrm{O}_{2}$ has been adjusted to the recently reported experimental value of 0.82 $\mathrm{eV}^{24}$ The difference between the experimental and calculated values can be traced to the arbitrariness in the choice of the initial state structure for the two $\left[\mathrm{Cu}\left(\mathrm{NH}_{3}\right)_{2}\right]^{+}$complexes $^{24}$ and the issue describing molecular oxygen with the applied exchange-correlation functional. ${ }^{38}$ In addition, the barriers for reactions $\mathrm{r} 8$ and $\mathrm{r} 10$ are set to $0.10 \mathrm{eV}$ instead of the computed zero barriers to avoid numerical instabilities.

The highest energy barriers $\left(\Delta E^{\ddagger}\right)$ in cycle I for $\mathrm{NH}_{3}$-SCR are the decomposition of $\mathrm{HONO}$ and $\mathrm{H}_{2} \mathrm{NNO}(\sim 0.4 \mathrm{eV})$, which is similar to the barrier for $\mathrm{N}_{2} \mathrm{O}$ formation. The highest barrier in cycle II is instead the formation of $\mathrm{H}_{2} \mathrm{NNO}$, which has a barrier of $0.62 \mathrm{eV}$. The barriers for $\mathrm{HONO}$ and $\mathrm{H}_{2} \mathrm{NNO}$ diffusion $(0.30$ $\mathrm{eV}$ ) are based on molecular dynamics simulations, which include both desorption from the $\mathrm{Cu}$ sites and passage through the eight-membered zeolite rings. 

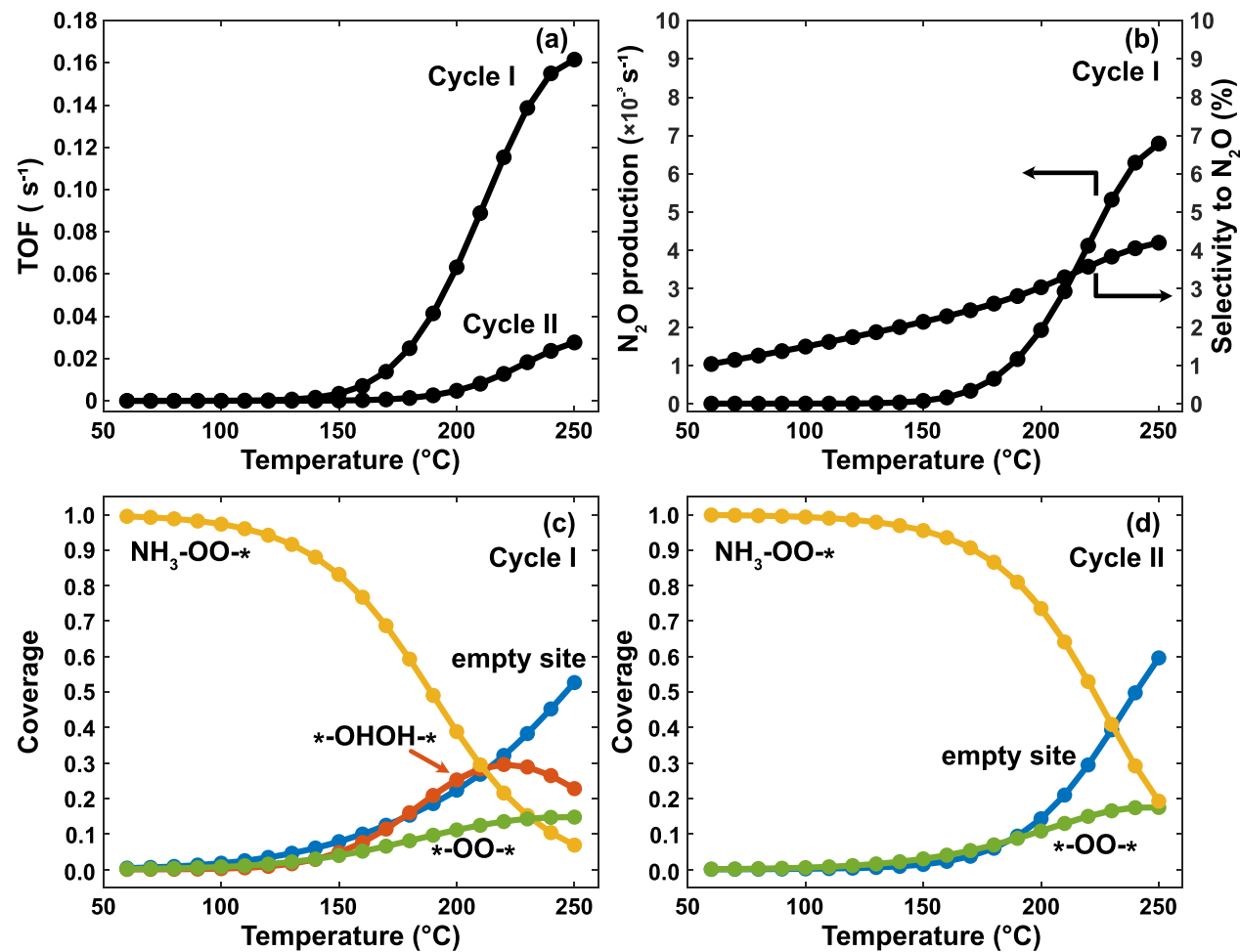

Figure 5. (a) Simulated turnover frequency for $\mathrm{NO}$ conversion over $\mathrm{Cu}-\mathrm{CHA}$ as a function of temperature in cycles I and II. (b) $\mathrm{N}_{2} \mathrm{O}$ formation and selectivity over $\mathrm{Cu}-\mathrm{CHA}$ in cycle I. (c, d) Coverage of dominating states in cycles I and II. The fractional coverage should in this case be understood as the fraction of $\mathrm{Cu}$ sites being in a certain state of the reaction cycle. The simulations are performed with $600 \mathrm{ppm} \mathrm{NH}_{3}, 500 \mathrm{ppm} \mathrm{NO}, 10 \% \mathrm{O}_{2}$, and balance $\mathrm{N}_{2}$.
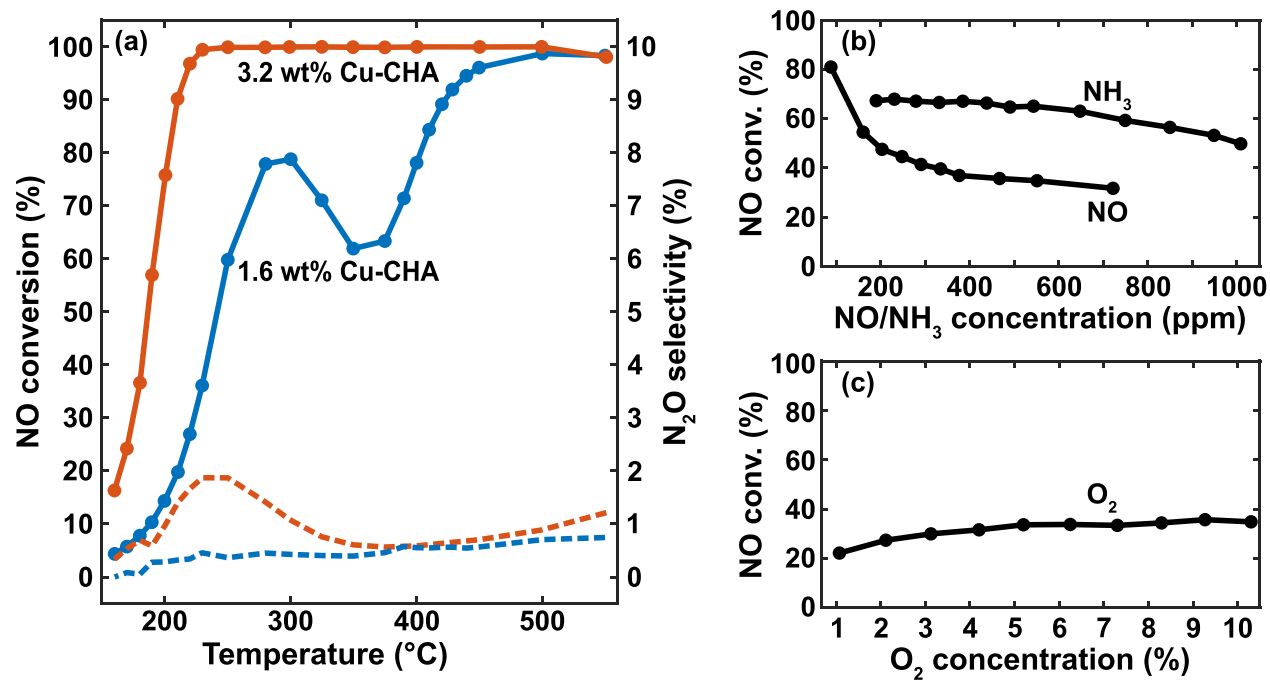

Figure 6. (a) $\mathrm{NO}$ conversion (solid lines) and $\mathrm{N}_{2} \mathrm{O}$ formation (dashed lines) versus temperature for standard $\mathrm{NH}_{3}$-SCR over the $1.6 \mathrm{wt} \% \mathrm{Cu}-\mathrm{CHA}$ (blue) and $3.2 \mathrm{wt} \% \mathrm{Cu}-\mathrm{CHA}$ (red) samples. Feed: $500 \mathrm{ppm} \mathrm{NO}, 600 \mathrm{ppm} \mathrm{NH}_{3}, 10 \% \mathrm{O}_{2}$, and balance $\mathrm{N}_{2}$. The conversion at $200{ }^{\circ} \mathrm{C}$ for the $1.6 \mathrm{wt} \%$ $\mathrm{Cu}-\mathrm{CHA}$ sample corresponds to an apparent reaction rate of $0.02 \mathrm{~mol} \mathrm{NO} /(\mathrm{mol} \mathrm{Cu} \cdot \mathrm{s})$. (b, c) NO conversion over the $1.6 \mathrm{wt} \% \mathrm{Cu}-\mathrm{CHA}$ sample versus the concentration of $\mathrm{NO}, \mathrm{NH}_{3}$, and $\mathrm{O}_{2}$ at $200^{\circ} \mathrm{C}$. In this series of experiments, individual feed gas concentrations are changed when all other feed gases concentrations are held constant. $\mathrm{NH}_{3}$ concentration is fixed to $843 \mathrm{ppm}$ when the NO concentration is varied. The NO concentration is set to 139 ppm when the $\mathrm{NH}_{3}$ concentration is varied. When the concentrations of $\mathrm{O}_{2}$ are changed from 1 to $10 \%$, the concentrations of $\mathrm{NH}_{3}$ and $\mathrm{NO}$ are set to 641 and 381 ppm, respectively. The balancing gas in the reaction order experiments is Ar.

As we consider the reaction over $\left[\mathrm{Cu}\left(\mathrm{NH}_{3}\right)_{2}\right]^{+}$complexes, the cycles describe standard $\mathrm{NH}_{3}$-SCR in the low-temperature regime (below $\sim 250{ }^{\circ} \mathrm{C}$ ), where the decomposition of the $\left[\mathrm{Cu}\left(\mathrm{NH}_{3}\right)_{2}\right]^{+}$complex is negligible. ${ }^{54}$ The model does not describe the reaction above $\sim 250{ }^{\circ} \mathrm{C}$, where the contribution of framework-bound $\mathrm{Cu}$ becomes important. ${ }^{54}$ The simulations are performed for a total pressure of 1 atm, with $600 \mathrm{ppm} \mathrm{NH}_{3}$, $500 \mathrm{ppm} \mathrm{NO}, 10 \%$ of $\mathrm{O}_{2}$, and balance $\mathrm{N}_{2}$. In the absence of reactants, the ratio between pairs of $\left[\mathrm{Cu}\left(\mathrm{NH}_{3}\right)_{2}\right]^{+}$complexes and the Brønsted acid sites is set to 1 .

Turnover Frequency (TOF) and Coverages. The calculated turnover frequencies (TOFs) of cycles I and II are presented in 
Figure 5a. The TOFs in both cycles have well-defined onset temperatures of about 120 and $170{ }^{\circ} \mathrm{C}$ in cycles I and II, respectively. The TOF of cycle I is significantly higher than that of cycle II. In both cases, the TOF begins to decrease at temperatures above $\sim 235{ }^{\circ} \mathrm{C}$. The decrease in TOF is due to low surface coverages as the decomposition of the $\left[\mathrm{Cu}\left(\mathrm{NH}_{3}\right)_{2}\right]^{+}$ complexes is not included in our model. The TOF is calculated as the number of consumed $\mathrm{NO}$ per $\mathrm{Cu}$ complex accounting for the probability of having two $\mathrm{Cu}$ complexes in the same $\mathrm{CHA}$ cage.

By comparing the turnover frequency and the coverages of the most abundant species reported in Figure $5 c$,d, it is clear that $\mathrm{NH}_{3}$ adsorption inhibits the $\mathrm{NH}_{3}$-SCR reaction in the lowtemperature regime $\left(<120^{\circ} \mathrm{C}\right)$. The coverage of inhibiting $\mathrm{NH}_{3}$ (denoted by $\mathrm{NH}_{3}-\mathrm{OO}-*$ ) is close to 1 below $100{ }^{\circ} \mathrm{C}$ for cycle $\mathrm{I}$, whereas this regime extends to $150{ }^{\circ} \mathrm{C}$ for cycle II. The inhibiting $\mathrm{NH}_{3}$ desorbs as the temperature is increased, allowing for the adsorption of $\mathrm{NO}$ and the formation of $\mathrm{H}_{2} \mathrm{NNO}$ and HONO. The TOF increases with increasing *-OHOH-* coverage, which peaks at $230{ }^{\circ} \mathrm{C}$. The number of empty sites increases and begins to dominate above $230{ }^{\circ} \mathrm{C}$, yielding a decrease in the TOF at high temperatures. The analysis of the coverages shows that the reaction at low temperatures is determined by the adsorption energy of the $\mathrm{NH}_{3}$ that blocks the $*-\mathrm{OO}-*$ sites. A weaker bond strength of $\mathrm{NH}_{3}-\mathrm{OO}-*$ would facilitate the reaction at lower temperatures.

Figure $5 \mathrm{~b}$ shows the TOF and the corresponding selectivity for $\mathrm{N}_{2} \mathrm{O}$ formation in cycle I. The temperature dependence of $\mathrm{N}_{2} \mathrm{O}$ formation is similar to that of $\mathrm{NH}_{3}$-SCR with a peak at 230 ${ }^{\circ} \mathrm{C}$. This is in agreement with experimental reports ${ }^{55,56}$ and a consequence of $\mathrm{N}_{2} \mathrm{O}$ formation over $\mathrm{Cu}$ sites via $\mathrm{H}_{2} \mathrm{NNO}$. The selectivity to $\mathrm{N}_{2} \mathrm{O}$ increases from 2 to $4 \%$ in the temperature interval of 150 to $250{ }^{\circ} \mathrm{C}$.

The $\mathrm{NH}_{3}-\mathrm{SCR}$ reaction is a multisite reaction requiring both $\mathrm{Cu}$ and Brønsted acid sites, whereas $\mathrm{N}_{2} \mathrm{O}$ formation only requires the $\mathrm{Cu}$ sites. This difference means that the $\mathrm{NH}_{3}$-SCR reaction depends on both the $\mathrm{Cu}$ loading and the $\mathrm{Cu} / \mathrm{Al}$ ratio, whereas $\mathrm{N}_{2} \mathrm{O}$ formation depends primarily on the $\mathrm{Cu}$ loading. This implies that the selectivity for $\mathrm{N}_{2}$ formation can be increased by decreasing the $\mathrm{Cu} / \mathrm{Al}$ ratio. In this case, reaction $\mathrm{r} 5$ is favored over reaction $\mathrm{r} 16$ as the ratio of Brønsted acid sites is increased with respect to $\mathrm{Cu}$ sites.

Comparison to Experimental Data. To verify the microkinetic model, we compare the results with a set of kinetic experiments. Figure $6 \mathrm{a}$ shows the temperature dependence of $\mathrm{NO}$ conversion and $\mathrm{N}_{2} \mathrm{O}$ selectivity for the $1.6 \mathrm{wt} \% \mathrm{Cu}-\mathrm{CHA}$ and $3.2 \mathrm{wt} \% \mathrm{Cu}-\mathrm{CHA}$ samples under standard SCR conditions. The conversion profile for the $1.6 \mathrm{wt} \% \mathrm{Cu}-\mathrm{CHA}$ catalyst shows the characteristic bimodal shape with a local maximum at about $275{ }^{\circ} \mathrm{C}$. The onset temperature for the conversion of $\mathrm{NO}$ decreases with increasing $\mathrm{Cu}$ loading. The apparent activation energies (Table 2) derived from the $\mathrm{NO}_{x}$ conversion experiments in the $160-240{ }^{\circ} \mathrm{C}$ range are 0.62 and $0.89 \mathrm{eV}$ for the 1.6 wt \% $\mathrm{Cu}-\mathrm{CHA}$ and 3.2 wt \% $\mathrm{Cu}-\mathrm{CHA}$ catalysts, respectively. The calculated apparent activation energies from the firstprinciples microkinetic model are $0.75 \mathrm{eV}$ for cycle I including $\mathrm{NH}_{3}$ inhibition, $0.31 \mathrm{eV}$ without $\mathrm{NH}_{3}$ inhibition (reaction $\mathrm{r} 15$ ), and $1.06 \mathrm{eV}$ for cycle II with inhibition. The higher activity together with an apparent activation energy matching the experiments points to cycle $\mathrm{I}$ as the main reaction path for $\mathrm{NH}_{3}$ SCR. Furthermore, the results show that the apparent activation energy for $\mathrm{NH}_{3}$-SCR mainly is determined by the $\mathrm{NH}_{3}$ inhibition of the $\left[\mathrm{Cu}_{2}\left(\mathrm{NH}_{3}\right)_{4} \mathrm{O}_{2}\right]^{2+}$ complex. The preference
Table 2. Apparent Activation Energy $\left(E_{\text {app }}\right)$ and Reaction Orders $\left(n_{\mathrm{x}}\right)$ from Experiments and the Kinetic Models ${ }^{a}$

\begin{tabular}{llrcrc} 
& \multicolumn{1}{c}{ exp. } & cycle I & $\begin{array}{c}\text { cycle I } \\
\text { (without } \\
\text { reaction r15) }\end{array}$ & $\begin{array}{c}\text { cycle II } \\
\text { (without } \\
\text { reaction r26) }\end{array}$ \\
\hline$E_{\text {app }}$ & $0.62 / 0.89$ & 0.75 & 0.31 & 1.06 & 0.05 \\
$n_{\mathrm{NH}_{3}}$ & -0.23 & -0.22 & 0.05 & -0.76 & 0.00 \\
$n_{\mathrm{NO}}$ & 0.73 & 0.95 & 0.92 & 1.00 & 0.99 \\
$n_{\mathrm{O}_{2}}$ & 0.25 & 0.23 & 0.34 & 0.15 & 0.58
\end{tabular}

${ }^{a_{T}}$ The simulated reaction orders are evaluated at $200{ }^{\circ} \mathrm{C}$. The energy is given in electronvolt.

of cycle I is supported by the thermodynamic preference for reaction $\mathrm{r} 2$ compared to reaction $\mathrm{r} 18$. The probability of following cycle I is about $98 \%$ in the considered temperature regime.

The selectivity for $\mathrm{N}_{2} \mathrm{O}$ is calculated for cycle I. To explore the dependence of the selectivity on the $\mathrm{Cu} / \mathrm{Al}$ ratio, we model the formation of $\mathrm{N}_{2} \mathrm{O}$ with different $\mathrm{Cu} / \mathrm{Al}$ ratios by changing the ratio between $\left[\mathrm{Cu}\left(\mathrm{NH}_{3}\right)_{2}\right]^{+}$and Brønsted acid sites in the model. Reducing the $\mathrm{Cu} / \mathrm{Al}$ ratio to 0.33 decreases the selectivity to $\mathrm{N}_{2} \mathrm{O}$ by a factor of 2 (see Figure $\mathrm{S} 6$ in the Supporting Information). The simulations match the experimental observation that $\mathrm{N}_{2} \mathrm{O}$ formation for the $3.2 \mathrm{wt} \% \mathrm{Cu}$ $\mathrm{CHA}$ catalyst $(\mathrm{Cu} / \mathrm{Al}$ ratio of 0.24$)$ is significantly higher than that for the $1.6 \mathrm{wt} \% \mathrm{Cu}-\mathrm{CHA}$ catalyst $(\mathrm{Cu} / \mathrm{Al}$ ratio of 0.12$)$.

The microkinetic model also predicts reaction orders with respect to $\mathrm{NH}_{3}, \mathrm{NO}$, and $\mathrm{O}_{2}$ in good agreement with experiments. Figure $6 \mathrm{~b}, \mathrm{c}$ shows the measured dependence of the $\mathrm{NO}_{x}$ conversion with changes in the partial pressures of $\mathrm{NH}_{3}, \mathrm{NO}$, and $\mathrm{O}_{2}$ for the 1.6 wt $\% \mathrm{Cu}-\mathrm{CHA}$ catalyst. The reaction orders for $\mathrm{NH}_{3}$-SCR derived from these data are -0.23 for $\mathrm{NH}_{3}, 0.73$ for $\mathrm{NO}$, and 0.25 for $\mathrm{O}_{2}$, which are in accordance with previous measurements. ${ }^{4,7,19,57}$ The values for $\mathrm{NO}$ and $\mathrm{O}_{2}$ agree very well with the calculated values of cycle I that includes the $\mathrm{NH}_{3}$ inhibition $\left(-0.22\right.$ for $\mathrm{NH}_{3}$, and 0.23 for $\left.\mathrm{O}_{2}\right)$, whereas the calculated reaction order for $\mathrm{NO}(0.95)$ is slightly higher than the measured value. The reaction order in $\mathrm{O}_{2}$ has been measured to decrease with increasing $\mathrm{O}_{2}$ pressure and increasing $\mathrm{Cu} / \mathrm{Al}$ ratio. ${ }^{57}$ The model reproduces these trends as shown in the Supporting Information (Table S1). The model also predicts the experimental increase in TOF as a function of $\mathrm{O}_{2}$ pressure (Figure S7). The reaction orders for cycle II are not in such good agreement with experiments, again indicating that cycle $\mathrm{I}$ is the main reaction path for $\mathrm{NH}_{3}$-SCR.

The reaction orders analysis further exemplifies that $\mathrm{NH}_{3}$ inhibition plays an important role in the kinetics of the $\mathrm{NH}_{3}$ SCR reaction. The negative reaction order with respect to $\mathrm{NH}_{3}$ is a direct consequence of the $\mathrm{NH}_{3}$ inhibition as clearly shown by the calculated reaction order of +0.05 when omitting the $\mathrm{NH}_{3}$ inhibition. Furthermore, the calculated apparent activation energy for cycle I becomes much lower, when the $\mathrm{NH}_{3}$ inhibition is omitted, showing that the apparent activation energy is determined by the desorption of inhibiting $\mathrm{NH}_{3}$. This indicates that the $\mathrm{NH}_{3}$ inhibition is a crucial reaction that should be included in kinetic models for $\mathrm{NH}_{3}$-SCR over $\mathrm{Cu}-\mathrm{CHA}$ at low temperatures.

The discrepancy between the calculated and measured reaction order with respect to $\mathrm{NO}$ is probably due to effects of residual water and parallel reactions on minority $\mathrm{Cu}$ sites, such as framework-bound $\mathrm{Cu}$, which could affect the reaction order. 
Degree of Rate Control Analysis for $\mathrm{NH}_{3}-\mathrm{SCR}$. The comparison to experiments shows that the first-principles microkinetic model captures the measured kinetic behavior. It motivates a further elaboration of which elementary steps that control the reaction by performing a degree of rate control $\left(\chi_{i}\right)$ analysis. $^{58}$ This analysis is performed by increasing the value of rate constants for the forward and backward reactions for each elementary step by $1 \%$ while keeping the equilibrium constant and the rate constants of all other reaction steps fixed. By calculating the response in the total TOF, the role of each elementary reaction is monitored. $\chi_{i}$ is calculated according to

$$
\chi_{i}=\frac{k_{i}}{r}\left(\frac{\partial \mathrm{TOF}}{\partial k_{i}}\right)_{K_{i}}
$$

The result of the degree of rate control analysis for $\mathrm{NH}_{3}$-SCR in cycle I is shown in Figure 7. We focus on cycle I, as this cycle

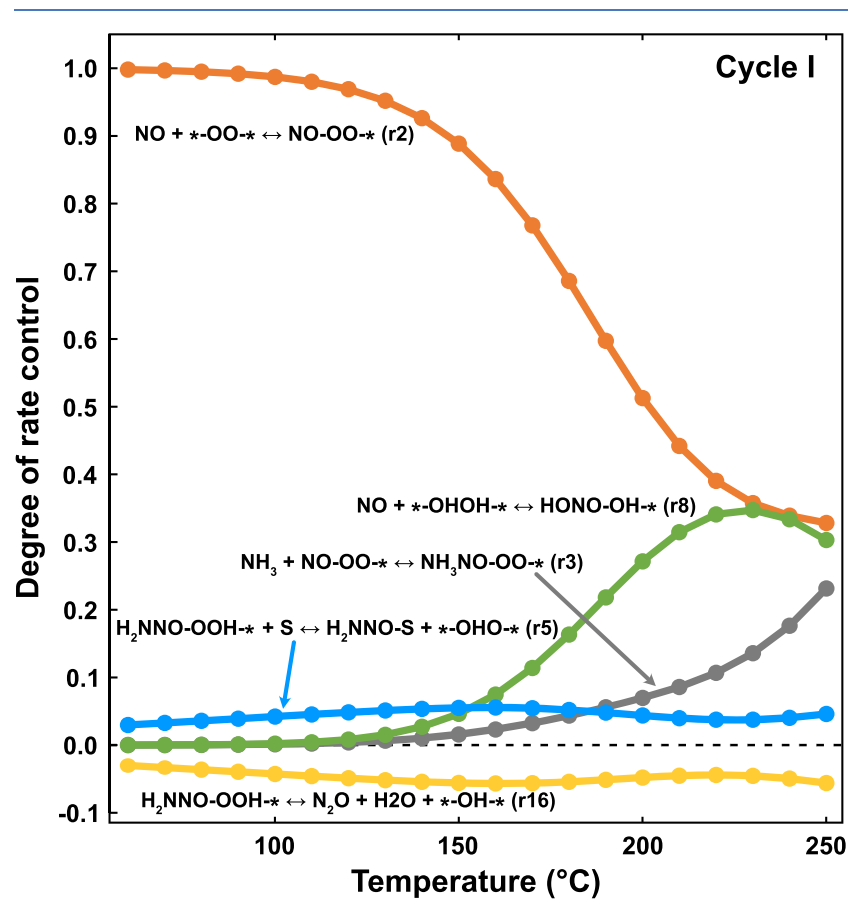

Figure 7. Degree of rate control analysis for $\mathrm{NH}_{3}$-SCR over $\mathrm{Cu}-\mathrm{CHA}$ in cycle I. The simulation is performed with $600 \mathrm{ppm} \mathrm{NH}_{3}, 500 \mathrm{ppm} \mathrm{NO}$, $10 \% \mathrm{O}_{2}$, and balance $\mathrm{N}_{2}$.

dominates the TOF and reproduces the measured reaction orders and apparent activation energy. Only the reactions with a notable degree of rate control are shown in Figure 7. The sum of all degrees of rate control is 1 .

At low temperatures, the rate of $\mathrm{NH}_{3}-\mathrm{SCR}$ is mainly determined by the $\mathrm{NO}$ adsorption step (reaction $\mathrm{r} 2$ ), as a consequence of the strong inhibition effect of $\mathrm{NH}_{3}$. As the temperature increases to $230{ }^{\circ} \mathrm{C}$, the controlling effect of $\mathrm{NO}$ adsorption is gradually reduced, whereas the formation of HONO-OH-* (reaction $\mathrm{r} 8$ ) becomes increasingly important. $\mathrm{NO}$ adsorption and $\mathrm{HONO}-\mathrm{OH}-*$ formation reach an equal degree of rate control at $230^{\circ} \mathrm{C}$, which is the temperature for the maximum TOF. The analysis shows that the $\mathrm{N}_{2} \mathrm{O}$ formation (reaction $\mathrm{r} 16$ ) is a competing reaction with a negative degree of rate control. The diffusion of $\mathrm{H}_{2} \mathrm{NNO}$ (reaction $\mathrm{r} 5$ ) from the $\mathrm{Cu}$ site to the Brønsted acid site has an opposite degree of rate control compared to reaction $\mathrm{r} 16$, which signals the branching in the reaction cycle.

\section{DISCUSSION AND SIMPLIFIED MODEL}

Having access to a first-principles microkinetic model makes it possible to link the kinetic behavior to certain reaction intermediates and structures in the $\mathrm{Cu}-\mathrm{CHA}$ catalyst. The apparent activation energy is related to the desorption of the inhibiting $\mathrm{NH}_{3}$, which blocks the $\left[\mathrm{Cu}_{2}\left(\mathrm{NH}_{3}\right)_{4} \mathrm{O}_{2}\right]^{2+}$ sites for $\mathrm{NO}$ adsorption. This explains the sizable apparent activation energy despite the flat potential energy landscape. The $\mathrm{NH}_{3}$ inhibition is also reflected in the negative reaction order with respect to $\mathrm{NH}_{3}$. The positive reaction order with respect to $\mathrm{O}_{2}$ is a consequence of that $\mathrm{O}_{2}$ adsorption is required for the $\mathrm{NH}_{3}$ SCR reaction over $\left[\mathrm{Cu}\left(\mathrm{NH}_{3}\right)_{2}\right]^{+}$pairs. The adsorption of $\mathrm{O}_{2}$ changes the oxidation state from $\mathrm{Cu}^{\mathrm{I}}$ to $\mathrm{Cu}^{\mathrm{II}}$, which allows for $\mathrm{NO}$ and $\mathrm{NH}_{3}$ adsorption and the subsequent formation of $\mathrm{H}_{2} \mathrm{NNO}$ and $\mathrm{HONO}$.

The alternation between $\mathrm{Cu}^{\mathrm{I}}$ and $\mathrm{Cu}^{\mathrm{II}}$ (and possibly $\mathrm{Cu}^{\mathrm{III}}$ ) is central for the function of the $\mathrm{Cu}-\mathrm{CHA}$ catalyst, and the temperature dependence of the $\mathrm{Cu}$-oxidation state has been measured to characterize the catalyst during reaction conditions. ${ }^{19,56}$ From an analysis of the $\mathrm{Cu}$ species present during the $\mathrm{NH}_{3}-\mathrm{SCR}$ reaction, we find that the fractions of $\mathrm{Cu}^{\mathrm{I}}$ and $\mathrm{Cu}^{\mathrm{II}}$ are around $50 \%$ in the considered temperature range (150-250 $\left.{ }^{\circ} \mathrm{C}\right)$. The fraction of $\mathrm{Cu}^{\mathrm{II}}$ reaches a maximum of $57 \%$ at $210{ }^{\circ} \mathrm{C}$ and decreases to $42 \%$ at $250{ }^{\circ} \mathrm{C}$ (see Figure S9 in the Supporting Information). The calculated values match experimental reports on the basis of in situ X-ray absorption measurements. ${ }^{19}$

Although the microkinetic model gives a precise description of the $\mathrm{NH}_{3}$-SCR reaction, it is a complicated reaction network that contains 18 elementary steps. To connect to previous phenomenological models, we simplify the atomistic model to only five reactions where we describe the adsorption of $\mathrm{O}_{2}$ over a pair of $\left[\mathrm{Cu}\left(\mathrm{NH}_{3}\right)_{2}\right]^{+}$, the adsorption of $\mathrm{NO}$ and $\mathrm{NH}_{3}$ on the $\left[\mathrm{Cu}_{2}\left(\mathrm{NH}_{3}\right)_{4} \mathrm{O}_{2}\right]^{2+}$ complex as elementary steps and the formation of $\mathrm{N}_{2}$ and $\mathrm{H}_{2} \mathrm{O}$ are lumped in two steps as follows

$$
\begin{aligned}
& \mathrm{O}_{2}+2 * \stackrel{\mathrm{R} 3}{\leftrightarrow} *-\mathrm{OO}-* \\
& \mathrm{NO}+*-\mathrm{OO}-* \stackrel{\mathrm{R} 4}{\leftrightarrow} \mathrm{NO}-\mathrm{OO}-* \\
& \mathrm{NH}_{3}+*-\mathrm{OO}-* \stackrel{\mathrm{R} 5}{\leftrightarrow} \mathrm{NH}_{3}-\mathrm{OO}-* \\
& 4 \mathrm{NH}_{3}+3 \mathrm{NO}-\mathrm{OO}-* \stackrel{\mathrm{R} 6}{\leftrightarrow} 4 \mathrm{~N}_{2}+6 \mathrm{H}_{2} \mathrm{O}+6^{*} \\
& 2 \mathrm{NH}_{3}+\mathrm{NO}+\mathrm{NO}-\mathrm{OO}-* \\
& \stackrel{\mathrm{R} 7}{\leftrightarrow} \mathrm{N}_{2}+\mathrm{N}_{2} \mathrm{O}+3 \mathrm{H}_{2} \mathrm{O}+2^{*}
\end{aligned}
$$

These reactions for low-temperature $\mathrm{NH}_{3}$-SCR and $\mathrm{N}_{2} \mathrm{O}$ formation (see the SI for parameters) describe the temperature dependence of the TOF with reasonable accuracy, having an apparent activation energy of $0.86 \mathrm{eV}$ and reaction orders with respect to $\mathrm{O}_{2}, \mathrm{NO}$, and $\mathrm{NH}_{3}$ of $0.2,1.2$, and -0.3 , respectively. We find it important to treat the adsorption of $\mathrm{O}_{2}, \mathrm{NO}$, and $\mathrm{NH}_{3}$ explicitly to obtain a qualitative agreement with the detailed model, which is consistent with the kinetic analysis showing that these adsorption steps control the reaction. Our simplified model can be compared to the phenomenological model in ref 14 , where the lumped $\mathrm{NH}_{3}$-SCR reaction was reported to have an apparent activation energy of $0.71 \mathrm{eV}$. Our analysis shows 
that the apparent activation energy is related to the desorption of $\mathrm{NH}_{3}$ from the $\left[\mathrm{Cu}_{2}\left(\mathrm{NH}_{3}\right)_{4} \mathrm{O}_{2}\right]^{2+}$ complex.

\section{CONCLUSIONS}

We have developed a first-principles microkinetic model for lowtemperature $\mathrm{NH}_{3}$-SCR and $\mathrm{N}_{2} \mathrm{O}$ formation over $\mathrm{Cu}-\mathrm{CHA}$ catalysts, based on DFT calculations and detailed entropy analysis. The model includes $\mathrm{H}_{2} \mathrm{NNO}$ and $\mathrm{HONO}$ formation over mobile $\mathrm{Cu}$ species together with $\mathrm{N}_{2}$ and $\mathrm{H}_{2} \mathrm{O}$ formation over Brønsted acid sites. $\mathrm{N}_{2} \mathrm{O}$ formation is included via $\mathrm{H}_{2} \mathrm{NNO}$ decomposition over $\mathrm{Cu}$ sites. The calculated values for activation energy and reaction orders for $\mathrm{NO}, \mathrm{NH}_{3}$, and $\mathrm{O}_{2}$, based on this microkinetic model, agree well with experimentally determined values. The favorable comparison between the model and the kinetic experiments strengthens the validity of the suggested multisite reaction mechanisms for low-temperature $\mathrm{NH}_{3}$-SCR and $\mathrm{N}_{2} \mathrm{O}$ formation over $\mathrm{Cu}-\mathrm{CHA}$.

The atomistic description allows for a clear link between kinetic behavior and materials properties. At low temperatures, $\mathrm{NH}_{3}$ inhibits the reaction by occupying $\mathrm{Cu}$ sites for $\mathrm{NO}$ adsorption. The $\mathrm{NH}_{3}$ inhibition is reduced with increasing temperature allowing for $\mathrm{NO}$ adsorption and subsequent formation of $\mathrm{HONO}$ and $\mathrm{H}_{2} \mathrm{NNO}$. The potential energy surface is flat, and the low-temperature apparent activation energy is determined by the adsorption energy of the inhibiting $\mathrm{NH}_{3}$, which hinders the reaction at low temperatures.

We find that $\mathrm{N}_{2} \mathrm{O}$ selectivity is moderately affected by the temperature. Thus, $\mathrm{N}_{2} \mathrm{O}$ selectivity cannot be steered by controlling the operational temperature. However, as lowtemperature $\mathrm{N}_{2}$ formation requires both $\mathrm{Cu}$ and Brønsted acid sites, whereas $\mathrm{N}_{2} \mathrm{O}$ formation requires only $\mathrm{Cu}$ sites, $\mathrm{Cu} / \mathrm{Al}$ ratio and $\mathrm{Al}$ distribution may provide handles to reduce $\mathrm{N}_{2} \mathrm{O}$ emissions.

Our work demonstrates the capabilities of first-principles microkinetic models for reactions in zeolites with dynamic active sites. The developed model advances the conceptual understanding of low-temperature $\mathrm{NH}_{3}$-SCR over $\mathrm{Cu}-\mathrm{CHA}$, rationalizes previous phenomenological models, and can be used to further enhance the performance of the catalyst.

\section{ASSOCIATED CONTENT}

\section{(5) Supporting Information}

The Supporting Information is available free of charge at https://pubs.acs.org/doi/10.1021/acscatal.1c03973.

Energy landscapes for cycles I and II, $\mathrm{H}_{2} \mathrm{NNO}$ adsorption on the $\left[\mathrm{Cu}\left(\mathrm{NH}_{3}\right)_{4} \mathrm{OOH}\right]^{2+}$ complex, energy profile for $\mathrm{H}_{2} \mathrm{NNO}$ diffusion, fit of entropy scaling factor by comparison with the $\mathrm{NH}_{3}$ temperature-programmed desorption (TPD) profiles, analysis of the effect of $\mathrm{Cu}$ / $\mathrm{Al}$ ratio on selectivity, dependence of $\mathrm{O}_{2}$ reaction order on oxygen pressure, temperature-dependent fractions of $\mathrm{Cu}^{\mathrm{I}}$ and $\mathrm{Cu}{ }^{\mathrm{II}}$, parameters and results of the simplified kinetic model (PDF)

Atomic structure files (ZIP)

\section{AUTHOR INFORMATION}

\section{Corresponding Authors}

Yingxin Feng - Department of Physics and Competence Centre for Catalysis, Chalmers University of Technology, SE-412 96

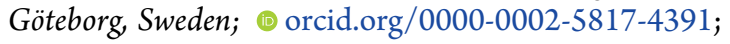
Email: yingxin@chalmers.se
Henrik Grönbeck - Department of Physics and Competence Centre for Catalysis, Chalmers University of Technology, SE41296 Göteborg, Sweden; (1) orcid.org/0000-0002-87092889; Email: ghj@chalmers.se

\section{Authors}

Xueting Wang - Department of Physics and Competence Centre for Catalysis, Chalmers University of Technology, SE-412 96 Göteborg, Sweden

Ton V. W. Janssens - Umicore Denmark ApS, DK-2970 Hørsholm, Denmark; 이이.org/0000-0002-1225-0942

Peter N. R. Vennestrøm - Umicore Denmark ApS, DK-2970 Hørsholm, Denmark; 이이.org/0000-0002-6744-5640

Jonas Jansson - Volvo Group Trucks Technology, SE-405 08 Göteborg, Sweden

Magnus Skoglundh - Department of Physics and Competence Centre for Catalysis, Chalmers University of Technology, SE41296 Göteborg, Sweden; (1) orcid.org/0000-0001-79467137

Complete contact information is available at:

https://pubs.acs.org/10.1021/acscatal.1c03973

\section{Notes}

The authors declare no competing financial interest.

\section{ACKNOWLEDGMENTS}

The authors thank Lin Chen for discussions on the reaction cycles. They acknowledge financial support from the Swedish Energy Agency (47110-1). The Competence Centre for Catalysis is hosted by Chalmers University of Technology and financially supported by the Swedish Energy Agency and the member companies $\mathrm{AB}$ Volvo, ECAPS $\mathrm{AB}$, Johnson Matthey $A B$, Preem AB, Scania CV AB, and Umicore Denmark ApS. The calculations have been performed at C3SE (Göteborg) through an SNIC grant.

\section{REFERENCES}

(1) Nova, I.; Tronconi, E. Urea-SCR Technology for DeNO $\mathrm{N}_{x}$ after Treatment of Diesel Exhausts; Springer Science + Business Media: New York, 2014; pp 1-10.

(2) Schmieg, S. J.; Oh, S. H.; Kim, C. H.; Brown, D. B.; Lee, J. H.; Peden, C. H.; Kim, D. H. Thermal Durability of $\mathrm{Cu}-\mathrm{CHA} \mathrm{NH} \mathrm{N}_{3}$-SCR Catalysts for Diesel $\mathrm{NO}_{\mathrm{x}}$ Reduction. Catal. Today 2012, 184, 252-261.

(3) Xin, Y.; Li, Q.; Zhang, Z. Zeolitic Materials for DeNO $_{x}$ Selective Catalytic Reduction. Chem CatChem 2018, 10, 29-41.

(4) Bates, S. A.; Verma, A. A.; Paolucci, C.; Parekh, A. A.; Anggara, T.; Yezerets, A.; Schneider, W. F.; Miller, J. T.; Delgass, W. N.; Ribeiro, F. $\mathrm{H}$. Identification of the Active $\mathrm{Cu}$ Site in Standard Selective Catalytic Reduction with Ammonia on Cu-SSZ-13. J. Catal. 2014, 312, 87-97.

(5) Gao, F.; Mei, D.; Wang, Y.; Szanyi, J.; Peden, C. H. Selective Catalytic Reduction over Cu/SSZ-13: Linking Homo- and Heterogeneous Catalysis. J. Am. Chem. Soc. 2017, 139, 4935-4942.

(6) Gao, F.; Walter, E. D.; Kollar, M.; Wang, Y.; Szanyi, J.; Peden, C. H. Understanding Ammonia Selective Catalytic Reduction Kinetics over Cu/SSZ-13 from Motion of the Cu Ions. J. Catal. 2014, 319, 1-14.

(7) Shih, A. Synthesis and Characterization of Copper-Exchanged Zeolite Catalysts and Kinetic Studies on $\mathrm{NO}_{\mathrm{x}}$ Selective Catalytic Reduction with Ammonia. Ph.D. thesis, Purdue University, 2019.

(8) Daya, R.; Keturakis, C. J.; Trandal, D.; Kumar, A.; Joshi, S. Y.; Yezerets, A. Alternate Pathway for Standard SCR on Cu-Zeolites with Gas-Phase Ammonia. React. Chem. Eng. 2021, 6, 1042-1052.

(9) Kumar, A.; Kamasamudram, K.; Currier, N.; Yezerets, A. SCR Architectures for Low $\mathrm{N}_{2} \mathrm{O}$ Emissions, SAE Technical Paper Series, 2015; pp 2-7. 
(10) Shan, Y.; Shi, X.; He, G.; Liu, K.; Yan, Z.; Yu, Y.; He, H. Effects of $\mathrm{NO}_{2}$ Addition on the $\mathrm{NH}_{3}$-SCR over Small-Pore Cu-SSZ-13 Zeolites with Varying Cu Loadings. J. Phys. Chem. C 2018, 122, 25948-25953.

(11) Cui, Y.; Gao, F. Cu Loading Dependence of Fast $\mathrm{NH}_{3}$-SCR on $\mathrm{Cu} /$ SSZ-13. Emiss. Control Sci. Technol. 2019, 5, 124-132.

(12) Feng, Y.; Janssens, T. V. W.; Vennestrøm, P. N. R.; Jansson, J.; Skoglundh, M.; Grönbeck, $\mathrm{H}$. The Role of $\mathrm{H}^{+}$- and $\mathrm{Cu}^{+}$-Sites for $\mathrm{N}_{2} \mathrm{O}$ Formation during $\mathrm{NH}_{3}$-SCR over $\mathrm{Cu}-\mathrm{CHA}$. J. Phys. Chem. C 2021, 125, 4595-4601.

(13) Clark, A. H.; Nuguid, R. J. G.; Steiger, P.; Marberger, A.; Petrov, A. W.; Ferri, D.; Nachtegaal, M.; Kröcher, O. Selective Catalytic Reduction of $\mathrm{NO}$ with $\mathrm{NH}_{3}$ on Cu-SSZ-13: Deciphering the Low and High-Temperature Rate-Limiting Steps by Transient XAS Experiments. Chem CatChem 2020, 12, 1429-1435.

(14) Olsson, L.; Wijayanti, K.; Leistner, K.; Kumar, A.; Joshi, S. Y.; Kamasamudram, K.; Currier, N. W.; Yezerets, A. A Multi-Site Kinetic Model for $\mathrm{NH}_{3}$-SCR over Cu/SSZ-13. Appl. Catal., B 2015, 174-175, 212-224.

(15) Shwan, S.; Skoglundh, M.; Lundegaard, L. F.; Tiruvalam, R. R.; Janssens, T. V. W.; Carlsson, A.; Vennestrøm, P. N. Solid-State IonExchange of Copper into Zeolites Facilitated by Ammonia at Low Temperature. ACS Catal. 2015, 5, 16-19.

(16) Negri, C.; Borfecchia, E.; Cutini, M.; Lomachenko, K. A.; Janssens, T. V. W.; Berlier, G.; Bordiga, S. Evidence of Mixed-Ligand Complexes in $\mathrm{Cu}-\mathrm{CHA}$ by Reaction of $\mathrm{Cu}$ Nitrates with $\mathrm{NO} / \mathrm{NH}_{3}$ at Low Temperature. ChemCatChem 2019, 11, 3828-3838.

(17) Paolucci, C.; Khurana, I.; Parekh, A. A.; Li, S.; Shih, A. J.; Li, H.; Di Iorio, J. R.; Albarracin-Caballero, J. D.; Yezerets, A.; Miller, J. T.; et al. Dynamic Multinuclear Sites Formed by Mobilized Copper Ions in $\mathrm{NO}_{\mathrm{x}}$ Selective Catalytic Reduction. Science 2017, 357, 898-903.

(18) Chen, L.; Janssens, T. V. W.; Vennestrøm, P. N.; Jansson, J.; Skoglundh, M.; Grönbeck, H. A Complete Multisite Reaction Mechanism for Low-Temperature $\mathrm{NH}_{3}$-SCR over Cu-CHA. ACS Catal. 2020, 10, 5646-5656.

(19) Paolucci, C.; Parekh, A. A.; Khurana, I.; Di Iorio, J. R.; Li, H.; Albarracin Caballero, J. D.; Shih, A. J.; Anggara, T.; Delgass, W. N.; Miller, J. T.; et al. Catalysis in a Cage: Condition-Dependent Speciation and Dynamics of Exchanged Cu Cations in SSZ-13 Zeolites. J. Am. Chem. Soc. 2016, 138, 6028-6048.

(20) Paolucci, C.; Di Iorio, J. R.; Schneider, W. F.; Gounder, R. Solvation and Mobilization of Copper Active Sites in Zeolites by Ammonia: Consequences for the Catalytic Reduction of Nitrogen Oxides. Acc. Chem. Res. 2020, 53, 1881-1892.

(21) Chen, L.; Falsig, H.; Janssens, T. V. W.; Grönbeck, H. Activation of Oxygen on $\left(\mathrm{NH}_{3}-\mathrm{Cu}-\mathrm{NH}_{3}\right)^{+}$in $\mathrm{NH}_{3}-\mathrm{SCR}$ over $\mathrm{Cu}-\mathrm{CHA}$. J. Catal. 2018, 358, 179-186.

(22) Negri, C.; Selleri, T.; Borfecchia, E.; Martini, A.; Lomachenko, K. A.; Janssens, T. V. W.; Cutini, M.; Bordiga, S.; Berlier, G. Structure and Reactivity of Oxygen-Bridged Diamino Dicopper(II) Complexes in CuIon-Exchanged Chabazite Catalyst for $\mathrm{NH}_{3}$-Mediated Selective Catalytic Reduction. J. Am. Chem. Soc. 2020, 142, 15884-15896.

(23) Oda, A.; et al. Spectroscopic Evidence of Efficient Generation of Dicopper Intermediate in Selective Catalytic Reduction of NO over Cu-Ion-Exchanged Zeolites. ACS Catal. 2020, 12333-12339.

(24) Wang, X.; Chen, L.; Vennestrøm, P. N.; Janssens, T. V.; Jansson, J.; Grönbeck, H.; Skoglundh, M. Direct Measurement of Enthalpy and Entropy Changes in $\mathrm{NH}_{3}$ Promoted $\mathrm{O}_{2}$ Activation over $\mathrm{Cu}-\mathrm{CHA}$ at Low Temperature. ChemCatChem 2021, 13, 2577-2582.

(25) Solomon, E. I.; Heppner, D. E.; Johnston, E. M.; Ginsbach, J. W.; Cirera, J.; Qayyum, M.; Kieber-Emmons, M. T.; Kjaergaard, C. H.; Hadt, R. G.; Tian, L. Copper Active Sites in Biology. Chem. Rev. 2014, 114, 3659-3853.

(26) DuBois, J. L.; Mukherjee, P.; Stack, T. D.; Hedman, B.; Solomon, E. I.; Hodgson, K. O. A Systematic K-edge X-ray Absorption Spectroscopic Study of $\mathrm{Cu}(\mathrm{III})$ Sites. J. Am. Chem. Soc. 2000, 122, 5775-5787.

(27) Gramigni, F.; Nasello, N. D.; Usberti, N.; Iacobone, U.; Selleri, T.; Hu, W.; Liu, S.; Gao, X.; Nova, I.; Tronconi, E. Transient Kinetic Analysis of Low-Temperature $\mathrm{NH}_{3}-\mathrm{SCR}$ over $\mathrm{Cu}-\mathrm{CHA}$ Catalysts
Reveals a Quadratic Dependence of $\mathrm{Cu}$ Reduction Rates on $\mathrm{Cu}^{\mathrm{II}}$. ACS Catal. 2021, 11, 4821-4831.

(28) De-La-Torre, U.; Pereda-Ayo, B.; Gutiérrez-Ortiz, M. A.; González-Marcos, J. A.; González-Velasco, J. R. Steady-State $\mathrm{NH}_{3}-$ SCR Global Model and Kinetic Parameter Estimation for $\mathrm{NO}_{\mathrm{x}}$ Removal in Diesel Engine Exhaust Aftertreatment with $\mathrm{Cu} / \mathrm{Chabazite}$. Catal. Today 2017, 296, 95-104.

(29) Bendrich, M.; Scheuer, A.; Hayes, R. E.; Votsmeier, M. Unified Mechanistic Model for Standard SCR, Fast SCR, and $\mathrm{NO}_{2}$ SCR over a Copper Chabazite Catalyst. Appl. Catal., B 2018, 222, 76-87.

(30) Oka, K.; Ohori, T.; Itagaki, Y.; Osumi, K.; Ishikawa, N.; Dobashi, Y.; Wako, E. In Improvement in Selective Catalytic Reduction Model Accuracy for Predicting $\mathrm{NO}_{x}$ Conversion at High Temperature, SAE Technical Paper Series, 2018; pp 1-12.

(31) Eijima, W.; Shibata, G.; Shibayama, N.; Kobashi, Y.; Ogawa, H.; Shimizu, K.-i. Kinetic Modeling of Steady-State $\mathrm{NH}_{3}$-SCR over a Monolithic Cu-CHA Catalyst. Catal. Today 2020, 352, 237-242.

(32) Kresse, G.; Hafner, J. Ab Initio Molecular Dynamics for OpenShell Transition Metals. Phys. Rev. B: Condens. Matter Mater. Phys. 1993, 48, 13115-13118.

(33) Kresse, G.; Hafner, J. Ab Initio Molecular-Dynamics Simulation of the Liquid-Metalamorphous-Semiconductor Transition in Germanium. Phys. Rev. B: Condens. Matter Mater. Phys. 1994, 49, 1425114269.

(34) Kresse, G.; Furthmüller, J. Efficient Iterative Schemes for Ab Initio Total-Energy Calculations Using a Plane-Wave Basis Set. Phys. Rev. B: Condens. Matter Mater. Phys. 1996, 54, 11169-11186.

(35) Kresse, G.; Furthmüller, J. Efficiency of Ab-Initio Total Energy Calculations for Metals and Semiconductors using a Plane-Wave Basis Set. Comput. Mater. Sci. 1996, 6, 15-50.

(36) Blöchl, P. E. Projector Augmented-Wave Method. Phys. Rev. B: Condens. Matter Mater. Phys. 1994, 50, 17953-17979.

(37) Kresse, G.; Joubert, D. From Ultrasoft Pseudopotentials to the Projector Augmented-Wave Method. Phys. Rev. B: Condens. Matter Mater. Phys. 1999, 59, 1758-1775.

(38) Perdew, J. P.; Burke, K.; Ernzerhof, M. Generalized Gradient Approximation Made Simple. Phys. Rev. Lett. 1996, 77, 3865-3868.

(39) Isseroff, L. Y.; Carter, E. A. Importance of Reference Hamiltonians Containing Exact Exchange for Accurate One-Shot GW Calculations of $\mathrm{Cu}_{2}$ O. Phys. Rev. B: Condens. Matter Mater. Phys. 2012, 85, No. 235142.

(40) Chen, L.; Janssens, T. V.; Grönbeck, H. A Comparative Test of Different Density Functionals for Calculations of $\mathrm{NH}_{3}$-SCR over $\mathrm{Cu}$ Chabazite. Phys. Chem. Chem. Phys. 2019, 21, 10923-10930.

(41) Grimme, S.; Antony, J.; Ehrlich, S.; Krieg, H. A Consistent and Accurate Ab Initio Parametrization of Density Functional Dispersion Correction (DFT-D) for the 94 Elements H-Pu. J. Chem. Phys. 2010, 132, No. 154104

(42) Grimme, S.; Ehrlich, S.; Goerigk, L. Effect of the Damping Function in Dispersion Corrected Density Functional Theory. J. Comput. Chem. 2011, 32, 1456-1465.

(43) Mills, G.; Jónsson, H.; Schenter, G. K. Reversible Work Transition State Theory: Application to Dissociative Adsorption of Hydrogen. Surf. Sci. 1995, 324, 305-337.

(44) Henkelman, G.; Jónsson, H. Improved Tangent Estimate in the Nudged Elastic Band Method for Finding Minimum Energy Paths and Saddle Points. J. Chem. Phys. 2000, 113, 9978-9985.

(45) Nosé, S. A Unified Formulation of the Constant Temperature Molecular Dynamics Methods. J. Chem. Phys. 1984, 81, 511-519.

(46) Hoover, W. G. Canonical Dynamics: Equilibrium Phase-Space Distributions. Phys. Rev. A 1985, 31, 1695-1697.

(47) Gao, F.; Washton, N.; Wang, Y.; Kollár, M.; Szanyi, J.; Peden, C. Effects of $\mathrm{Si} / \mathrm{Al}$ Ratio on $\mathrm{Cu} / \mathrm{SSZ}-13 \mathrm{NH}_{3}$-SCR Catalysts: Implications for the Active $\mathrm{Cu}$ Species and the Roles of Brønsted Acidity. J. Catal. 2015, 331, 25-38.

(48) Chorkendorff, I.; Niemantsverdriet, J. W. Concepts of Modern Catalysis and Kinetics; John Wiley \& Sons, 2017; pp 107-112. 
(49) Piccini, G.; Alessio, M.; Sauer, J. Ab Initio Calculation of Rate Constants for Molecule-Surface Reactions with Chemical Accuracy. Angew. Chem., Int. Ed. 2016, 55, 5235-5237.

(50) Jørgensen, M.; Chen, L.; Grönbeck, H. Monte Carlo Potential Energy Sampling for Molecular Entropy in Zeolites. J. Phys. Chem. C 2018, 122, 20351-20357.

(51) Chen, L.; Jansson, J.; Skoglundh, M.; Grönbeck, H. Mechanism for Solid-State Ion Exchange of $\mathrm{Cu}+$ into Zeolites. J. Phys. Chem. C 2016, 120, 29182-29189.

(52) Chen, L.; Falsig, H.; Janssens, T. V. W.; Jansson, J.; Skoglundh, M.; Grönbeck, $\mathrm{H}$. Effect of Al-distribution on oxygen activation over Cu-CHA. Catal. Sci. Technol. 2018, 8, 2131-2136.

(53) Li, J.; Li, S. New Insight into Selective Catalytic Reduction of Nitrogen Oxides by Ammonia over $\mathrm{H}$-form Zeolites: A Theoretical Study. Phys. Chem. Chem. Phys. 2007, 9, 3304-3311.

(54) Borfecchia, E.; Negri, C.; Lomachenko, K. A.; Lamberti, C.; Janssens, T. V. W.; Berlier, G. Temperature-Dependent Dynamics of $\mathrm{NH}_{3}$-Derived $\mathrm{Cu}$ Species in the Cu-CHA SCR Catalyst. React. Chem. Eng. 2019, 4, 1067-1080.

(55) Akter, N.; Chen, X.; Parise, J.; Boscoboinik, J. A.; Kim, T. Effects of Copper Loading on $\mathrm{NH}_{3}-\mathrm{SCR}$ and $\mathrm{NO}$ Oxidation over $\mathrm{Cu}$ Impregnated CHA Zeolite. Korean J. Chem. Eng. 2018, 35, 89-98.

(56) Fahami, A. R.; Günter, T.; Doronkin, D. E.; Casapu, M.; Zengel, D.; Vuong, T. H.; Simon, M.; Breher, F.; Kucherov, A. V.; Brückner, A.; et al. The Dynamic Nature of $\mathrm{Cu}$ Sites in Cu-SSZ-13 and the Origin of the Seagull $\mathrm{NO}_{x}$ Conversion Profile during $\mathrm{NH}_{3}$-SCR. React. Chem. Eng. 2019, 4, 1000-1018.

(57) Jones, C. B.; Khurana, I.; Krishna, S. H.; Shih, A. J.; Delgass, W. N.; Miller, J. T.; Ribeiro, F. H.; Schneider, W. F.; Gounder, R. Effects of Dioxygen Pressure on Rates of $\mathrm{NO}_{\mathrm{x}}$ Selective Catalytic Reduction with $\mathrm{NH}_{3}$ on Cu-CHA Zeolites. J. Catal. 2020, 389, 140-149.

(58) Campbell, C. T. Future Directions and Industrial Perspectives Micro- and Macro-Kinetics: Their Relationship in Heterogeneous Catalysis. Top. Catal. 1994, 1, 353-366. 